\title{
Paper Cuts: How Reporting Resources Affect Political News Coverage
}

\author{
Erik Peterson \\ Texas A\&M University \\ Department of Political Science \\ erik.peterson@tamu.edu*
}

Forthcoming at the American Journal of Political Science

\begin{abstract}
Media outlets provide crucial inputs into the democratic process, yet they face increasingly severe economic challenges. I study how a newly salient manifestation of this pressure, reduced reporting capacity, influences political coverage. Focusing on newspapers in the United States, where industry-wide employment fell over $40 \%$ between 2007 and 2015, I use panel data to assess the relationship between reporting capacity and political coverage. Staff cuts substantially decrease the amount of political coverage newspapers provide. Across different samples and measurement approaches, a typical cutback to a newspaper's reporting staff reduces its annual political coverage by between 300 and 500 stories. These political news declines happen against the backdrop of similar reductions in nonpolitical coverage, meaning the share of newspaper articles focused on politics remains stable over this period. This demonstrates that economic pressure affects the political information environment by shaping the media's capacity to cover politics.
\end{abstract}

*The author thanks Lauren Davenport, Johanna Dunaway, Sharad Goel, Justin Grimmer, Jay Hamilton, Shanto Iyengar, Jonathan Mummolo, Brian Rosenthal, Kathleen Searles, Gabor Simonovits and Sean Westwood for helpful comments and the American Society of Newsroom Editors and UNC's Center for Innovation and Sustainability in Local Media for sharing data. Stanford's Center for Philanthropy and Civil Society provided research support. 
The news media provides crucial inputs into the democratic process. In its capacity as a political observer, the media's coverage helps the public make sense of developments in institutions ranging from local school boards to the White House (Graber 1988, Mondak 1995, Jerit et al. 2006, Hayes and Lawless 2015, Rogers 2017, Peterson 2017). When operating as a political watchdog, media scrutiny exposes government corruption and motivates policy change (Puglisi and Snyder 2011, Boydstun 2013, Hamilton 2016).

Today the legacy media producing political coverage face severe economic pressures (Shaker 2014, Hayes and Lawless 2015, Hopkins 2018, Darr et al. 2018, Martin and McCrain 2019, Trussler ND). These challenges have been especially pronounced for newspapers in the United States where, due to drops in advertising revenue and the debt burdens carried by many chains, industry-wide employment fell by over $40 \%$ between 2007 and 2015 (ASNE 2016). The implications of these changes are important to understand. Newspapers provide crucial information to other media and local opinion leaders (Mondak 1995). Declines in reporting capacity raise concern they will transform from "keystones" of the political information environment (Nielsen 2015, see also Mahone et al. 2019) into "useless shells" with a limited ability to cover politics and scrutinize government (McChesney and Nichols 2011, 104; see also Abernathy 2018, Hayes and Lawless 2018, Van Aelst et al. 2017).

Here I argue that reporting resources influence the media's ability to cover politics, with reporting cutbacks leading to less political news. This explanation differs from others in several ways. First, it is distinct from alternatives that explain political coverage using the preferences of news consumers (Soroka 2014, Kernell et al. 2018), the views of ownership (Martin and McCrain 2019, Dunaway 2008, Schaffner and Sellers 2003) or media outlet structure (Cook 1989, Boydstun 2013). Second, other work considers how news outlets preemptively alter their coverage to head off economic challenges (Petrova 2011, Hamilton 2004). The present account picks up after such efforts fall short, identifying a channel through which economic pressures influence the availability of political information by shaping the 
media's capacity to cover politics.

To examine this resource-based account of political news coverage, I create measures of newspaper staffing from an industry census and digitized media directories. These complementary approaches overcome measurement challenges limiting prior tests of reporting capacity's role in political news production.

I relate reporting capacity to news coverage by measuring the amount of national, state and local political coverage in newspapers using keyword searches in news databases. Prior studies demonstrate the political importance of this outcome, with the supply of political news influencing aspects of mass behavior - such as public opinion, political knowledge and retrospective voting (Mondak 1995, Arnold 2004, Jerit et al. 2006, Prior 2007, Hopkins and Pettingill 2018, Rogers 2017, Peterson ND) - and elite-level politics - including candidate entry, the effort exerted by legislators and the composition of the policy-making agenda (Rubado and Jennings ND, Snyder and Strömberg 2010, Baumgartner and Jones 1993).

Descriptively, staff cutbacks are widespread and affect reporters in a variety of roles, including those with a political focus. They impact newspapers similarly whether or not they are owned by a national chain, showing declines in reporting resources are distinct from newspaper ownership. In terms of political news, industry-wide staffing declines coincide with substantial reductions in the volume of political coverage newspapers produce.

I use panel data to assess the within-newspaper relationship between newspaper staffing and the amount of political news, in both absolute terms and relative to other types of coverage, that a newspaper produces. Across multiple measurement approaches, I show staff declines reduce the amount of political coverage a newspaper provides. In the longest panel available for analysis, which covers 1994 to 2014, a typical decline in reporting capacity in the data, a loss of 12 reporters, reduces a newspaper's expected volume of political coverage by 500 stories per year, an amount equivalent to $5 \%$ of the average annual political coverage offered by newspapers in this sample. Among the stories newspapers still produce, the share 
of political news coverage is not affected by staff cuts. This stability occurs because political news declines happen against the backdrop of similar reductions in non-political coverage and means that, even as large absolute declines in political news coverage volume have occurred, political news has not been disproportionately affected by reporting cutbacks.

Beyond these overall effects, there is only mixed support for two additional hypotheses about the consequences of staffing declines for different types of coverage or due to the types of reporters they involve. There is suggestive evidence staff cuts are more impactful for local political news and when they involve reporters specializing on political topics, but these heterogeneous effects are imprecisely estimated and supportive evidence is not obtained across all the newspaper samples.

This analysis provides systematic evidence for how declines in newspaper reporting capacity affect political coverage. The consequences of media decline extend beyond high-profile newspaper shutdowns (Darr et al. 2018, Shaker 2014, Schulhofer-Wohl and Garrido 2013) or media with owners disinclined to invest in local reporting (Dunaway 2008, Darr 2014, Martin and McCrain 2019). Instead, reporting cutbacks occur across different ownership structures and influence the political coverage of many newspapers that continue to operate, but with severely reduced reporting staffs. Focusing on reporting capacity explains one source of the political coverage declines observed in other work (e.g., Hayes and Lawless 2018, Peterson ND). More broadly, this study highlights a theoretical perspective of growing importance for understanding political news in an era of declining resources at legacy media across the globe (Rubado and Jennings ND, Abernathy 2018, Van Aelst et al. 2017, Nielsen 2012).

\section{Economic Pressure and Political News Coverage}

Although economic considerations contributed to the formation of an independent press in the United States (Petrova 2011, Hamilton 2004), news outlets now face a tension between fulfilling the public service goals important to journalists (Weaver et al. 2007, 141-145; Gardner et al. 2001) and the pressures of a competitive marketplace (Kaniss 1991, McManus 1994, 
Hamilton 2004). Influential accounts explain features of contemporary political coverage the prevalence of "soft" news, a reliance on negatively framed stories, the presence of coverage with an ideological slant - using an anticipatory framework in which media outlets tailor their coverage to attract an audience and stave off threats to their economic viability (Kernell et al. 2018, Soroka 2014, Gentzkow and Shapiro 2010, Patterson 2000).

In this article I argue there is a second channel through which market pressures can affect political news. Anticipatory efforts to stave off economic decline can fall short, something increasingly common as broader technological changes undermine established media funding models (e.g., Seamans and Zhu 2014, Cagé ND). After these setbacks, news organizations are forced to adapt. As labor costs represent a substantial portion of most media outlets' variable expenditures (Kirchoff 2010), this response often takes the form of cuts to their reporting staff (Angelucci and Cagé 2019). Through this process economic pressure shapes a media outlet's capacity to produce political news by reducing its reporting resources.

\section{Reporting Capacity and Political News Coverage}

Changes in reporting capacity may impact political news because the creation of political coverage is heavily dependent on staffing. Ethnographic accounts of news production emphasize the intensive labor required to produce original political reporting (Tuchman 1978, Fishman 1980, Kaniss 1991, McManus 1994). These case studies document journalists' need to balance information collection from routinized sources, such as press conferences, with active efforts to develop contacts, follow leads and make public records requests. Consistent with this, newspapers with low circulation or owned by national chains, two contributors to lower reporting capacity, offer less or lower quality political coverage than their counterparts (Darr 2016, Dunaway 2008, Meyer 2008, Arnold 2004, Schaffner and Sellers 2003).

Given the important role of reporters, industry-wide staffing declines at daily newspapers have produced concern about the continued provision of political news (Jones 2009, Starr 2009, Hayes and Lawless 2018, Abernathy 2018). These declines stem from a combination 
of falling advertising revenues, difficulty in monetizing online readership and growing debt burdens at prominent newspaper chains (Zirchhoff 2010, Waldman 2011). Due to layoffs and buyouts, the number of newspaper employees fell from 55,000 in 2007 to 33,000 in 2015 in a census conducted by the American Society of Newsroom Editors (ASNE 2016).

Declines occurred throughout the industry with large-scale cutbacks at outlets with national profiles, such as the Los Angeles Times, and at newspapers, like the Raleigh News $\mathcal{E}^{\circ}$ Observer, that anchor regional coverage (e.g., Jones 2009, 9-12; Hamilton 2009). Cutbacks impacted journalists in a variety of roles, from the Chicago Sun-Times's decision to layoff its entire photography department (Channick 2013), to buyouts of experienced investigative reporters at the Washington Post (Waldman 2011).

The preceding discussion suggests staff declines may reduce the amount of political coverage newspapers provide. This is important due to the relationship between political coverage volume and political outcomes in previous work and concern that political events will go uncovered due to staff cuts (e.g., Snyder and Strömberg 2010, Hayes and Lawless 2018).

Beyond political news volume, a related question is how staffing declines impact the composition of newspaper's coverage. Media decline may disproportionally affect political news, leading to a lower share of newspaper coverage addressing politics. This could occur if newspapers preserve reporting staff and coverage in non-political domains to a greater extent than their political coverage, perhaps in an attempt to retain reader interest (e.g., Jones 2009). Alternatively, the same factors suggesting decreased reporting resources will reduce political coverage may also operate in other coverage domains. For instance, nonpolitical coverage of community events can also be labor-intensive and require journalists to follow similar news-gathering routines to political beat reporting. To address this second aspect of coverage, both a newspaper's political news volume and the share of its coverage focused on politics appear as outcomes in the analysis that follows.

So far discussion has centered on the implications of staffing for overall political coverage. 
There are reasons to suspect reporting resources to have heterogeneous consequences for different areas of political news coverage and based on the types of reporters involved. The next sections consider these possibilities.

\section{News Coverage Topic}

For some areas of politics there exist pooled resources, shared across outlets, offering coverage of a political institution. Wire services like the Associated Press allow outlets without dedicated reporters to cover national and state politics. Newspaper chains also combine the resources of outlets in the same region to cover state and national politics (Edna et al. 2014). In such situations, a media outlet's own reporting resources may have a more modest influence on its coverage as it can either run wire copy directly or use it as the basis for its own coverage $1^{1}$ For areas where these pooled resources do not exist, an outlet's staffing may have a more substantial relationship with news coverage as there are no alternatives for producing news coverage.

This creates a politically-relevant distinction as shared resources typically exist only for political offices representing a large number of people (Strömberg 2015, 187). Accordingly, one expectation is that the consequences of staffing declines will be larger for local political coverage, where alternatives are unavailable, than for other coverage areas.

\section{Reporter Specialization}

The organization of newsrooms means there may be different consequences based on the types of reporters involved in a cutback. Newspaper reporting occurs through a system of beats focused on a particular topics, leading to steady "police patrol" coverage of political institutions on common beats (Boydstun 2013). In contrast, reporters on non-political beats

\footnotetext{
${ }^{1}$ Some, but not all, of the wire copy in a newspaper is available in the electronic databases used for the analysis (Ridout et al. 2012). I discuss these issues when introducing the data used for the analysis and further address them in Appendix A.
} 
on sports or lifestyle coverage focus on those areas rather than politics. I expect the contribution of reporters with a political focus to be more pronounced than general assignment reporters or those with a non-political focus (e.g., sports or entertainment).

\section{Expectations}

The preceding discussion generates four expectations about the consequences of staffing declines. The first is that declines in staffing will reduce an outlet's overall attention to politics.

H1: Declines in newspaper staffing will reduce a newspaper's volume of political coverage

A second expectation that staff cuts will disproportionately impact political news relative to non-political coverage.

H2: Declines in newspaper staffing will reduce a newspaper's share of political coverage

Due to the particularly resource-intensive nature of local political reporting, a third hypothesis is that staffing will be particularly impactful for coverage of local politics.

H3: Declines in newspaper staffing will have a stronger effect on local political coverage relative to other coverage areas

Finally, a fourth hypothesis is that politically-focused staffing will have greater consequences for political news than reporters with no specialty or a non-political focus.

H4: Declines in politically-focused news reporters will have a stronger effect on political coverage than other types of reporters

An assessment of these hypotheses is needed for several reasons. First, there is limited evidence on how reporting resources affect political news. Ethnographic studies discuss reporting resources (Fishman 1980, Kaniss 1991), but focus on a small number of newspapers over a short window. Lacking direct measures of reporting capacity, past quantitative studies 
rely on proxies such as an outlet's subscriber base or ownership and make cross-sectional comparisons between different newspapers (Darr 2016, Hayes and Lawless 2015, Dunaway 2008, Arnold 2004). This limits their ability to distinguish the contribution of reporting resources from other variables.

Second, opposing theoretical considerations cast doubt on whether staff cuts will translate into political coverage declines. Newspapers may respond to economic pressure by increasing, or at least maintaining, local political coverage to differentiate themselves from other media. In line with this, George and Waldfogel (2006) find newspapers increased attention to local news due to the nationwide expansion of the New York Times.

Third, even as the number of reporters has declined, changes in news production may make staffing less relevant. Computer-assisted reporting allows individual reporters to do more work than in the past (Hamilton 2016, Ch. 8) and journalists now face increased productivity expectations (Starkman 2010), developments that may mute the consequences of staffing declines for political coverage volume.

\section{Measuring Newspaper Staffing and Political Coverage}

Understanding the consequences of declining reporting resources requires measuring newspaper staffing. Sources, such as journalist Erica Smith's Paper Cuts blog, initially tracked layoffs in 2007 based on tips and public announcements. However, such efforts cover a short

time period and it is unclear if they capture all relevant staffing changes. As a result, I introduce more comprehensive measures of newspaper staffing.

\section{Staffing Measure 1: ASNE Census}

ASNE's newsroom census provides a measure of staffing at newspapers across the country. This is collected through an annual survey sent to editors at every daily newspaper in the United States. It offers a long-term perspective on newspaper staffing that has received limited academic use (but see Meyer 2008, Rubado and Jennings ND). While industry-wide 
staffing data is publicly available, here I use restricted data on staffing at individual newspapers. A strength of this measure is the long time period over which it is available. The census provides newspaper-level counts of those working in newsrooms as editors, reporters, copyeditors or visual artists from 1994 to 2014. Importantly, it is collected with the knowledge individual newspapers will remain anonymous, encouraging a truthful account of a newspaper's staff size ${ }^{2}$

Against these strengths, the census does have drawbacks. It is subject to non-response when editors fail to return the survey, meaning not all newspapers are available over this time period if they never or rarely respond to the census. Using self-reports of staff size also potentially introduces measurement error if editors apply different criteria for determining job roles or newsroom size. Finally, the census combines different types of reporters into a single category, making it too coarse to isolate only those reporters with a political beat.

\section{Staffing Measure 2: Newspaper Directories}

To supplement the census and offset its drawbacks, I create a second measure of newspaper staffing from print copies of Bacon's Newspaper Directory, a trade publication containing contact information for newspaper editors and reporters $3^{3}$ These directories offer a comprehensive source of contact information for journalists and have been used to create a sampling frame for industry-wide surveys (Weaver et al. 2007). This measure was produced by extracting text from high-quality scans of over 9,000 pages of newspaper staff listings covering 2005 to 2012. Processing the text, which contains a consistent table format, provides another newspaper staffing measure. As the listings detail beat assignments, they also identify reporters focused on politics, something not possible in the census.

\footnotetext{
${ }^{2}$ Like others (Meyer 2008, Rubado and Jennings ND), I received access to newspaper-level data from ASNE on the condition that staffing at individual newspapers not be disclosed.

${ }^{3}$ Print publication of the directories stopped after 2012. Archived versions of the digital media directories are not available from Bacons/Cision.
} 
The directory supplements the census by measuring staffing on different beats and providing an assessment of newsroom size that does not rely on survey self-reports. However, it is available over a more limited window of time than the census. Because the census and directory have their own strengths and weaknesses, the analysis that follows includes both whenever possible to determine whether results are robust to different measures of newspaper staffing. This offers clear support for findings that are consistent across these different approaches to measuring newspaper staffing and, given the individual drawbacks of each measure, suggests a more cautious interpretation of findings that cannot be replicated using both.

\section{Outcome Measure: Newspaper Attention to Politics}

I link staffing to a newspaper's attention to politics. I operationalize media attention as counts of the number of newspaper stories containing keywords associated with different political offices or the names of public officials, which follows research using similar measures to examine the amount of political information in newspapers (e.g., Snyder and Strömberg 2010, Hayes and Lawless 2015, Hopkins 2018, Ban et al. 2019).

Story count data came from two sources. The first is Newsbank. Stories were identified with keyword searches for a set of terms related to political coverage developed by Hopkins (2018, Ch. 6). These terms touch on national, state and local politics. I create a summary measure of a newspaper's overall attention to politics and a separate measure of stories on local politics (see Appendix A for detail). The sample from this source consists of a long panel of newspapers ( $n=70$ newspapers) where data on coverage and staffing is available from 1994 to 2014 and a short panel (n=192 newspapers) from 2000 to 2014 that incorporates additional newspapers with data only available over the more recent time window.

The second coverage source is the Proquest database $(n=170$ newspapers). Here stories were identified using searches for terms related to four different political coverage areas, providing separate measures of attention in each domain. National news coverage was identified 
from articles referencing the incumbent president. State news coverage was identified based on articles with the name of the state's incumbent governor. Two aspects of local political coverage - local government coverage of mayors or city councils and local education coverage of school boards - were identified using keywords associated with these offices. This provides annual counts for each topic for 170 newspapers from 2004 to 2014.

Across the different sources, the sample includes newspapers in every state. It also includes an influential set of outlets. In 2014, the 319 newspapers available from at least one coverage source had a combined print circulation of over 20 million, representing $49 \%$ of the daily newspaper circulation in the United States that year.

There are two methodological issues with this dependent variable I briefly address. First, although using keywords to identify political coverage is common, this approach can sometimes fail to capture its intended content (King et al. 2017). I draw on original and secondary validation of the keywords in this study to show they capture news outcomes of interest. The summary measures of overall and local media attention used for Newsbank were previously validated by Hopkins (2018, Ch. 6). In identifying national and state coverage with officeholder names in Proquest, I rely on research showing this captures relevant political dynamics (e.g., political influence, Ban et al. 2019; news media attention to Congress, Snyder and Strömberg 2010). Finally, several measures of classifier performance in Appendix A show the keywords used to identify local education and local government coverage effectively capture the intended news compared to labels produced by human coders for a sample of stories.

Second, Ridout et al. (2012) find that electronic newspaper databases do not include some wire coverage that appears in print in newspapers.4 This means the databases could exaggerate declines in political coverage if newspapers increasingly substitute wire

\footnotetext{
${ }^{4}$ Appendix A.4 uses a similar audit of the correspondence between print newspapers and the coverage in electronic databases to show the same concern applies in this analysis
} 
service coverage for their own content over the period considered here. In Appendix A, I use digitized scans to directly examine the number of pages with political keywords in print newspapers and find a similar trend in political coverage to the electronic newspaper databases, suggesting the databases do not exaggerate political coverage declines. While this convergence is reassuring, the issue Ridout et al. (2012) raise does highlight a benefit of using multiple keyword choices and databases to assess the robustness of results across different approaches to measuring political news.

\section{Describing Newspaper Staffing and Political Coverage}

Before relating staffing to coverage, I begin by describing staff cuts at newspapers and changes in political news coverage. Figure 1 describes the substantial loss of reporters that occurred at newspapers in the sample. The left panel of Figure 1 shows the average reporting staff at newspapers where coverage can be paired with staffing in the census from 1994 to 2014. There is a $42 \%$ decline in newspaper staffing, from an average reporting staff of 75 in 1994 to 44 in 2014.

The right panel focuses on the broader newspaper sample over the recent window in Proquest. The black line represents the census staffing measure, which declined by $26 \%$ between 2004 and 2014. The average number of reporters employed at a newspaper declined from 46 to 34 at the end of the panel. The gray line displays average staffing at the same newspapers using the directory measure. This alternative also reveals substantial staff declines, as the average number of reporters fell from 35 in 2005 to 22 in 2012. 
Figure 1: Newspaper Reporters By Year
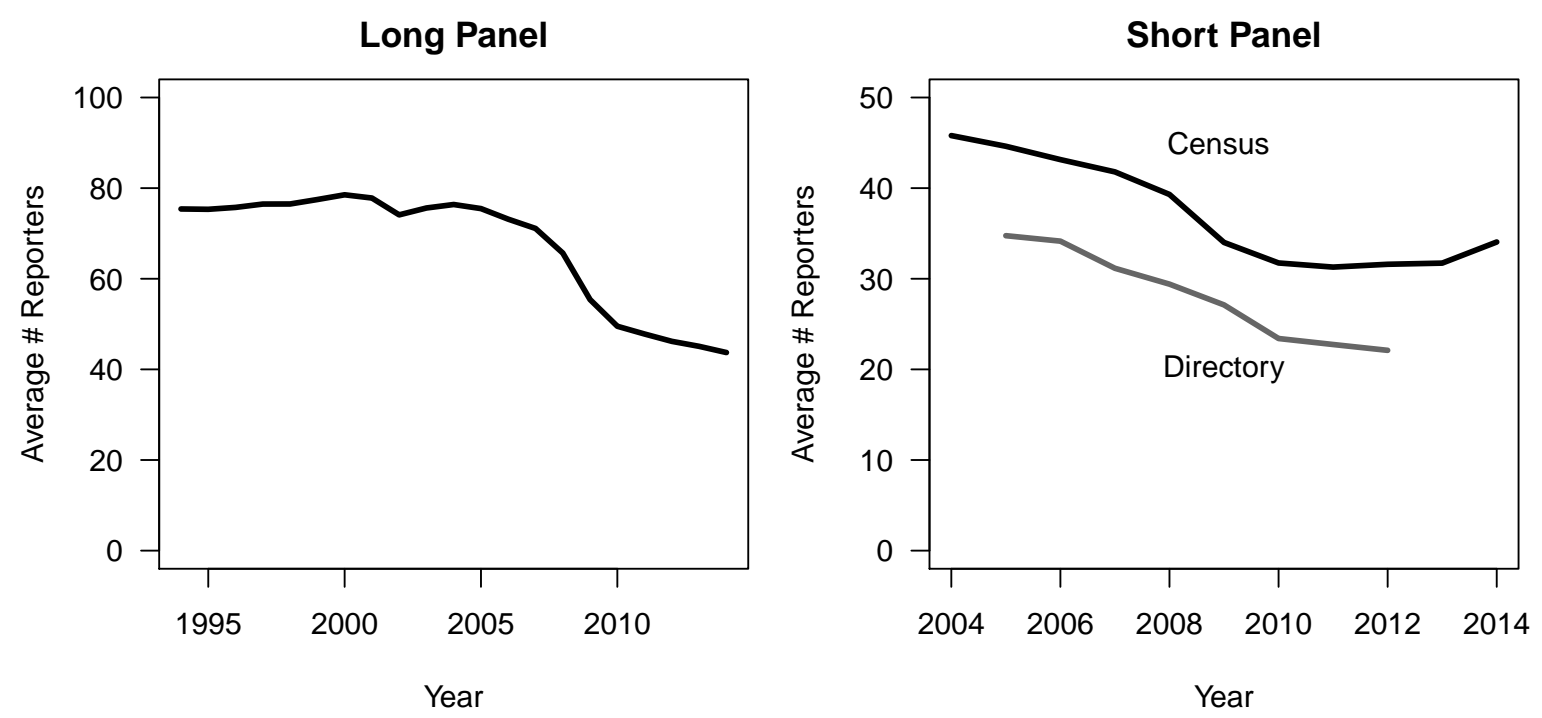

Note: Figure displays the average staff size at newspapers where coverage data is available. The left panel shows newspapers available from 1994 to 2014, the right panel shows newspapers for 2004 to 2014 .

For newspaper-years where both are available, the two measures are similar, with a correlation over .95. However, modest differences exist between them. For instance, average levels of reporting are higher in the census. Given the difficulty in portraying either as the "ground truth" for newspaper staffing, I use both when possible to ensure any result is robust to different operationalizations of newsroom size. $5^{5}$

\section{Staffing By Ownership Type}

Previous studies emphasize media ownership's role in political news coverage (Martin and McCrain 2019, Arnold 2004). Accordingly, it is important to understand the relationship between ownership and staffing before proceeding. One possibility is that a newspaper's ownership largely explains staffing declines, with cuts concentrated among newspapers owned by national chains, a group identified as making less reporting investment than others (Dunaway 2008, Schaffner and Sellers 2003). Figure 2 considers this by comparing the census

${ }^{5}$ Appendix B shows these measures exhibit strong convergent validity and also correspond with public reports of newspaper layoffs. 
staffing measure at newspapers owned by national chains to other newspapers ${ }^{6}$

Figure 2: Newspaper Reporters By Year (National Chain/Non-National Chain)

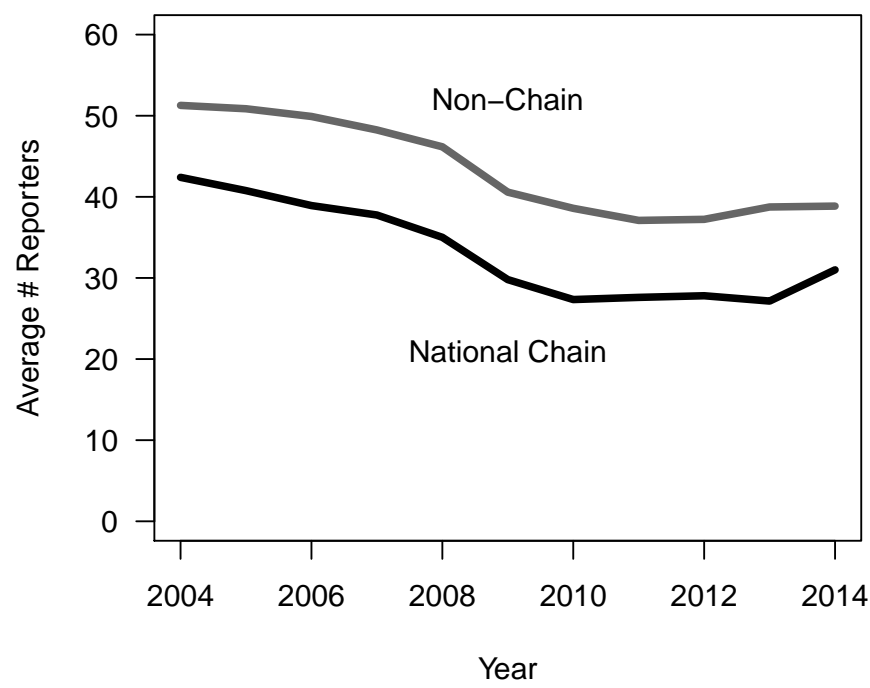

Note: Figure displays the average staff size at newspapers where coverage data is available based on whether or not they were a member of a national chain in 2008 .

Consistent with earlier work, newspapers owned by national chains have less reporting capacity over the entire time period. However, staff declines happen in parallel among both types of newspapers. Among national chains, staffing fell by $27 \%$ during these years. It fell by $24 \%$ among non-chain owned newspapers. This shows staff cuts occur throughout the newspaper industry and are not confined to one ownership structure and emphasizes newsroom size as a distinct explanatory variable to consider separately from ownership in the analysis that follows..$^{7}$

\section{Reporter Composition}

How does the overall decline impact different reporting beats? I use staff lists in the directories to categorize reporters into three mutually exclusive groups: political reporters,

${ }^{6}$ See Appendix C for definitions. This is based on a newspaper's ownership in 2008.

${ }^{7}$ Appendix Table $\mathrm{C} 2$ shows the relationship between reporters and news coverage remains when controlling for within-newspaper variation in chain ownership. 
entertainment reporters and a residual category of those not in either group. The political category contains reporters focused on government institutions (e.g., city hall) or with a geographic focus (e.g, metro reporters) likely to contribute to political coverage. This includes $45 \%$ of the reporters in the sample. The entertainment category consists of the $35 \%$ of reporters focused on sports, culture, health/fitness or other non-political topics. Finally, the "other" category includes the $20 \%$ of reporters without a specific listing (e.g., "news reporter") or beats that only occasionally touch on politics (e.g., economic reporters).$^{8}$

Figure 3: Reporter Composition By Year

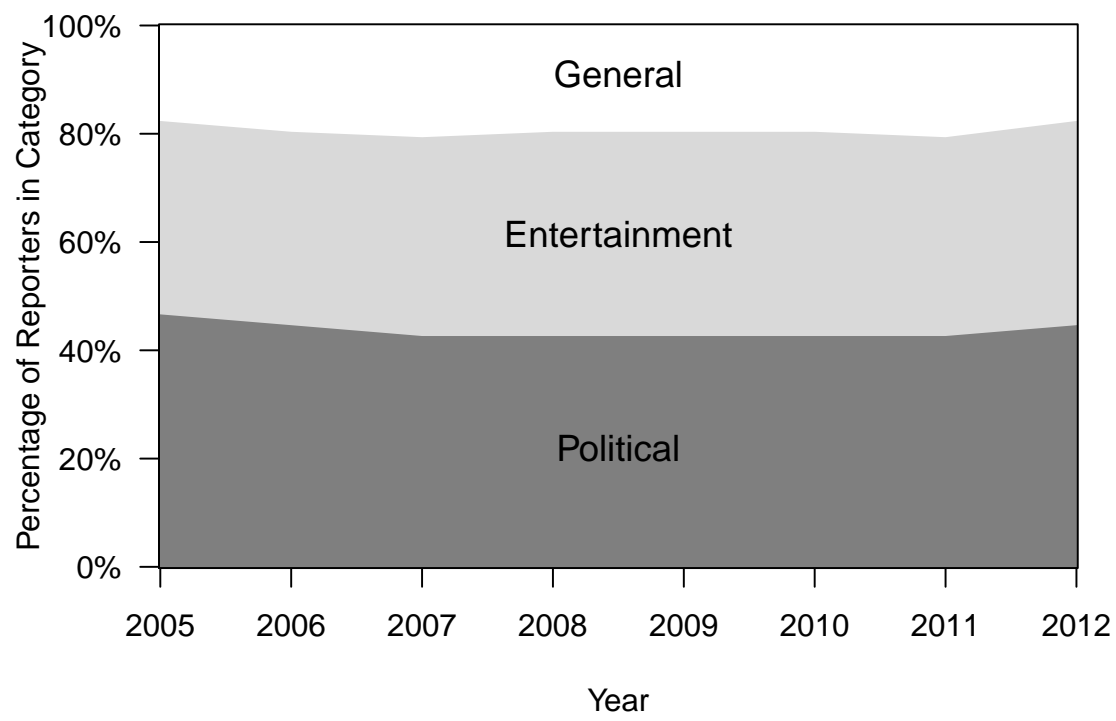

Note: Figure displays the share of reporters on different beats for newspapers where coverage data is available for the directory measure of staffing.

Figure 3 displays the composition of reporting staff by year, which is largely stable. Even as cutbacks occurred throughout the newspaper industry, they did not alter the share of reporters on various beats. This pattern is inconsistent with concern that staff cuts would disproportionately impact political reporters relative to reporters on non-political beats (e.g., Jones 2009). Instead it suggests the prominence of non-topical criteria, such as seniority or salary, in staffing decisions at newspapers during this time.

\footnotetext{
${ }^{8}$ Appendix B offers more information about reporters in each category.
} 


\section{Political News Coverage}

Moving to news coverage, Figure 4 describes the amount of attention newspapers devote to politics over this time period. The left panel displays the overall amount of political coverage from newspapers available beginning in 1994. There is a substantial drop in both overall political coverage, which declined $48 \%$ between 1994 and 2014, and in news focused on local politics, which fell by $46 \%$ over the same period. The amount of political news produced by newspapers exhibits a pronounced dip from 2007 to 2009, coinciding with the most severe staff cuts displayed in Figure 1.

Figure 4: Political News Coverage By Year
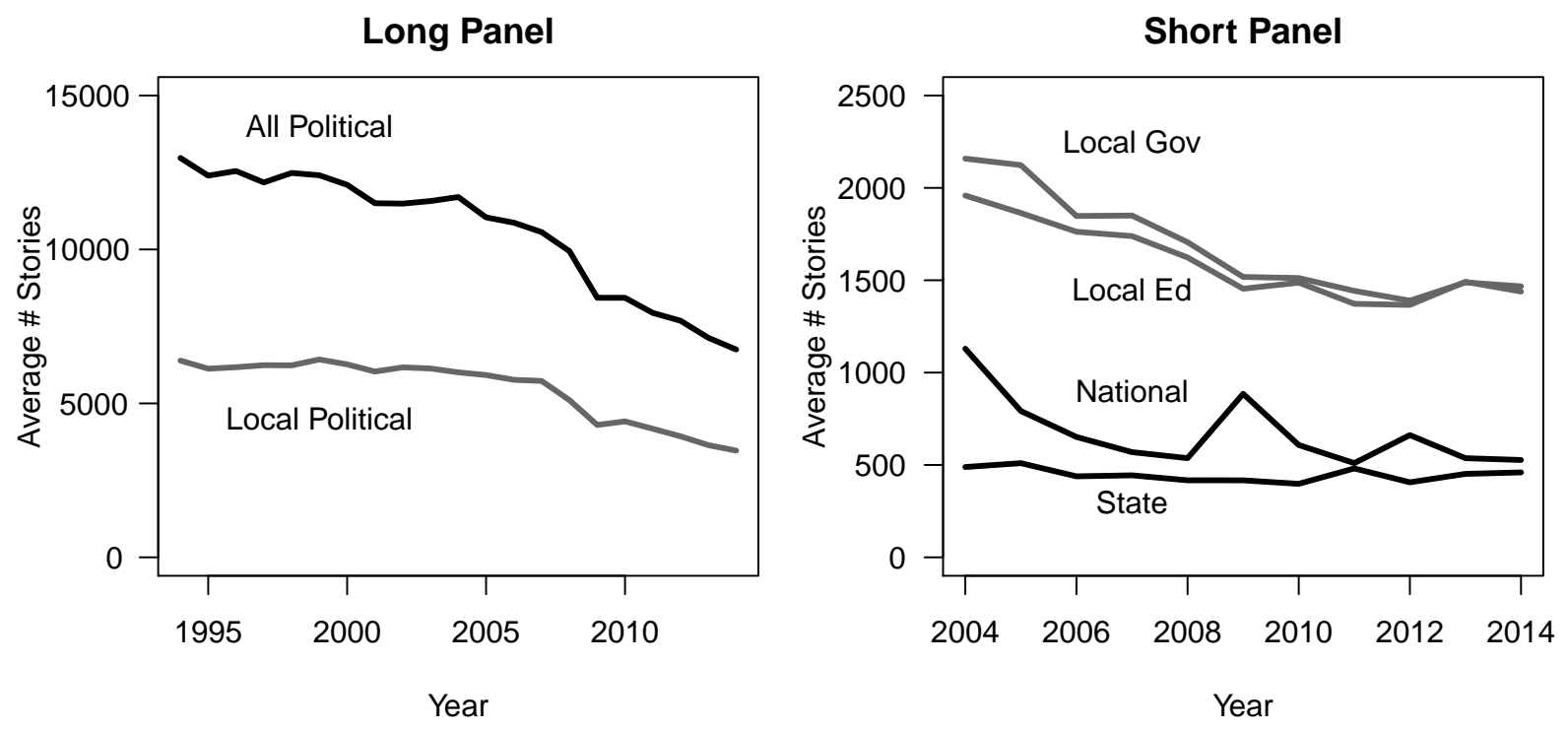

Note: Figure displays the average staff size at newspapers where coverage data is available. The left panel shows newspapers available from 1994 to 2014, the right panel shows newspapers for 2004 to 2014 .

The right panel displays political coverage in four different topic areas between 2004 and 2014 for newspapers in Proquest. Coverage of state politics is relatively stable, while national national coverage of the President falls over this window, except for an uptick in 2009. Drop-off occurs in both aspects of local political coverage. The average number of articles on local government, for instance, falls from 2,200 in 2004 to 1,500 in 2014 . 
Across both outcomes the composition of political coverage, in terms of the share that deals with local politics, exhibits limited change even as there is an overall decline in the amount of political news. In the long panel, local political coverage comprises $49 \%$ of news stories in 1994 and $51 \%$ of political news articles in 2014. In the shorter panel, which uses a different set of keywords these types of political news stories, local political coverage comprises $72 \%$ of political articles in 2004 and $75 \%$ in 2014. Despite these baseline differences in coverage share in the two sources, both show a similar temporal pattern: attention to local and national political topics declines at roughly similar rates over this period (see Appendix C for more descriptives on political coverage by year).

\section{Relating Reporting Resources to Political Coverage}

Having described these patterns in newspaper staffing and political coverage, I now turn to a more direct assessment of the relationship between them by estimating the effect of newspaper staffing on coverage in a series of panel regressions. These models take the following form, where $p$ indexes newspapers and $t$ indexes years:

$$
\text { Political Coverage }_{p t}=\beta_{0}+\beta_{1} \text { Reporters }_{p t}+\alpha_{t}+\alpha_{p}+\gamma_{p t}+\epsilon_{p t}
$$

Political Coverage C $_{\text {r }}$ represents a newspaper's article count in a coverage area during a year. Reporters $s_{p t}$ is a newspaper's number of reporters in the same year. $\alpha_{t}$ and $\alpha_{p}$ are year and newspaper fixed effects that confine the model to variation in newspaper staffing and coverage unexplained by fixed characteristics of a newspaper or temporal shocks common to all newspapers in the sample. Finally, $\gamma_{p t}$ contains a series of time-varying controls potentially related to political coverage. This includes its overall circulation and demographics of its home county $!^{9} \quad$ These variables help account for alternative explanations for a newspaper's

${ }^{9}$ The 2004-2014 analysis conditions on additional market features, such as a newspaper's share of circulation in its home county, that are unavailable over the entire 1994 to 2014 
coverage and address confounding that might otherwise result from changes in a newspaper's coverage due to shifts in its audience, rather than changes in its reporting staff.10

This approach offers several advantages for understanding the contribution of newspaper staffing to political coverage. This panel establishes a baseline of media attention prior to staffing declines. The year fixed effects ensure that temporal changes in coverage patterns are not misattributed to the broad shocks to staffing across the newspaper industry as a whole or common temporal changes faced by all newspapers (e.g., the growth in online news consumption). Finally, the use of newspaper fixed effects means this model examines the consequences of within-paper variation in staffing on coverage, removing concerns that stable between-outlet differences that existed prior to declines in staffing explain coverage differences between newspapers.

\section{Political News Coverage Volume}

In this section, I assess the relationship between a newspaper's staffing and the amount of political coverage it produces. Table 1 reports the results of regressions using several operationalizations of both coverage and staffing, an approach used here and in some subsequent analyses to examine the robustness of the relationship across difference samples and measurement approaches.

The first column displays results for the 1994-2014 newspaper sample in Newsbank (n=70 newspapers) and uses the reporting measure from the ASNE census. The second column does so for the broader sample of 192 newspapers available using these same sources of coverage and staffing data for 2000-2014. The third column conducts this analysis, again using the census staffing measure, but substituting the coverage data available from Proquest for 170 newspapers from 2004 to 2014. Here an overall measure of political news coverage time period. Results also remain the same when controlling for changes in a newspaper's ownership during this time period (see Appendix Table C2).

${ }^{10}$ Appendix $\mathrm{C}$ contains a full list of these variables and their sources. 
was constructed by summing the number of stories in the four individual coverage areas. Finally, the fourth column uses the same outcome measure, but includes the directory-based measure of newspaper staffing available for 2005 to 2012 ( $\mathrm{n}=186$ newspapers). In all cases, standard errors are clustered by newspaper.

Table 1: Reporters and Overall Political News Coverage

\begin{tabular}{lccrr}
\hline & Model 1 & Model 2 & Model 3 & Model 4 \\
\hline Reporters & $40.15^{*}$ & $60.38^{*}$ & $42.68^{*}$ & $44.87^{*}$ \\
& $(14.71)$ & $(11.96)$ & $(9.23)$ & $(7.48)$ \\
\hline$N$ & 1470 & 2880 & 1606 & 1449 \\
\hline Coverage Source & Newsbank & Newsbank & Proquest & Proquest \\
Staffing Source & Census & Census & Census & Directory \\
Time Period & $1994-2014$ & $2000-2014$ & $2004-2014$ & $2005-2012$ \\
\hline
\end{tabular}

Robust standard errors, clustered by Newspaper, in parentheses

Models include Newspaper Fixed Effects, Year Fixed Effects and News Market controls

* indicates significance at $p<0.05$

The coefficient for reporters indicates the change in the number of political stories produced by a newspaper due to a one reporter shift in its staff size. This coefficient is positive and statistically significant across the various sources of staffing and political coverage, indicating that higher levels of staffing are related to more political news ${ }^{11}$ This relationship supports a resource-based perspective on the production of political coverage. The similar findings across the different measurements provide confidence this relationship does not stem from idiosyncrasies in how news coverage or reporting resources are measured. Most importantly, Table 1 directly links the declines in newspaper staffing and political news coverage separately described in preceding sections, showing this relationship holds within newspapers and net of controls for a variety of other factors that shape political coverage.

The substantive implications of these estimates of the relationship between newspaper

\footnotetext{
${ }^{11}$ Results remain similar in models that do not include the newspaper market control variables (see Table D2). Also, see Table D3 for a table including the coefficients for these control variables.
} 
staffing and news coverage merit additional discussion, as they indicate changes in staffing produce meaningful shifts in political news coverage. In the model 1 specification that covers the longest time window, a one standard deviation decline in a newspaper's reporting staff, roughly 12 reporters, produces an expected 500 story decline in its overall political news coverage ${ }^{12}$ This amounts to $5 \%$ of the average amount of annual political coverage offered by the newspapers in this sample. In the model 4 specification, covering the shorter time window and using the directory staffing measure, a one standard deviation change in reporting staff leads to an expected 318 story decline in the amount of political coverage a newspapers produces, or $9 \%$ of the average amount of political coverage offered by newspapers in this sample.

\section{Robustness: Newspaper-Specific Time Trends}

While the preceding analysis addresses important sources of confounding, it relies on the assumption that newspapers would share parallel trends in their coverage absent staffing changes. This is a strong assumption, particularly as changes in the media environment over this time period may have impacted newspapers in the sample differently. For this reason, it is important to consider whether similar results can be observed without it.

I now relax this assumption by estimating models that include separate linear time trends for each newspaper, accounting for any differential trends in political news coverage that are unique to a given newspaper. It is important to note that this more flexible alternative is not without its own drawbacks. The use of unit trends may attenuate estimates of the relationship between staffing because these trends are constructed, in part, based on periods after substantial declines in staffing occur (see Meer and West 2016 for a discussion of

\footnotetext{
${ }^{12}$ These typical changes are based on a one standard deviation shift in the residual variation in reporting staff net of other model covariates (Mummolo and Peterson 2018). This withinunit measure reflects the variation in newspaper staffing used to estimate the model after including fixed effects and other controls.
} 
these issues). However, this comparison between the different model specifications remains valuable as an examination of whether the relationship between newspaper staffing and political coverage is robust to relaxing a key assumption in the preceding analysis.

Table 2: Reporters and Overall Political News Coverage (With Linear Newspaper Trends)

\begin{tabular}{lcccc}
\hline & Model 1 & Model 2 & Model 3 & Model 4 \\
\hline Reporters & $30.86^{*}$ & $26.01^{*}$ & 11.40 & 11.98 \\
& $(13.86)$ & $(10.97)$ & $(8.80)$ & $(6.53)$ \\
\hline$N$ & 1470 & 2880 & 1606 & 1449 \\
\hline Coverage Source & Newsbank & Newsbank & Proquest & Proquest \\
Staffing Source & Census & Census & Census & Directory \\
Time Period & $1994-2014$ & $2000-2014$ & $2004-2014$ & $2005-2012$ \\
\hline
\end{tabular}

Robust standard errors, clustered by Newspaper, in parentheses

Models include Newspaper Fixed Effects, Year Fixed Effects and News Market controls

* indicates significance at $p<0.05$

Table 2 displays the results from this alternative specification. Across the various samples and measurement approaches, incorporating newspaper-specific time trends attenuates the coefficients on reporting staff. However, in a supportive point for a resource-based perspective on the production of political news coverage, in all specifications a positive relationship between staffing and coverage remains. For the two panels that cover the longest period of time, the relationship between a newspaper's reporting capacity and its political coverage remains large and statistically significant. The relationship is smaller, and no longer statistically significant, in the short panels.

The primary contribution of Table 2 is to show that the relationship between staffing and news coverage does not hinge on the parallel trends assumption. Even after incorporating unit trends, a sizable relationship between newspaper staffing and political coverage remains in the panels that cover longer windows of time, highlighting the robustness of the evidence for the long term relationship between staffing and news coverage. However, this examination also shows the analyses that cover a shorter time window rely on this assumption more heavily, as unit trends reduce the size of the relationship between staffing and coverage. 


\section{Political News Coverage Share}

Beyond the volume of political coverage newspapers produce, another consideration is the composition of this coverage. Do staff cutbacks affect political news more than other forms of coverage and reduce the share of politically-focused news? I consider a newspaper's share of political coverage by dividing the amount of political coverage a newspaper provides by the total number of articles, of any type, that appeared in it during a given year. I collected this overall measure of coverage for newspapers in Newsbank from 2000 to 2014 and so focus only on this source here.

Figure 5: Overall Coverage and Political Coverage Share
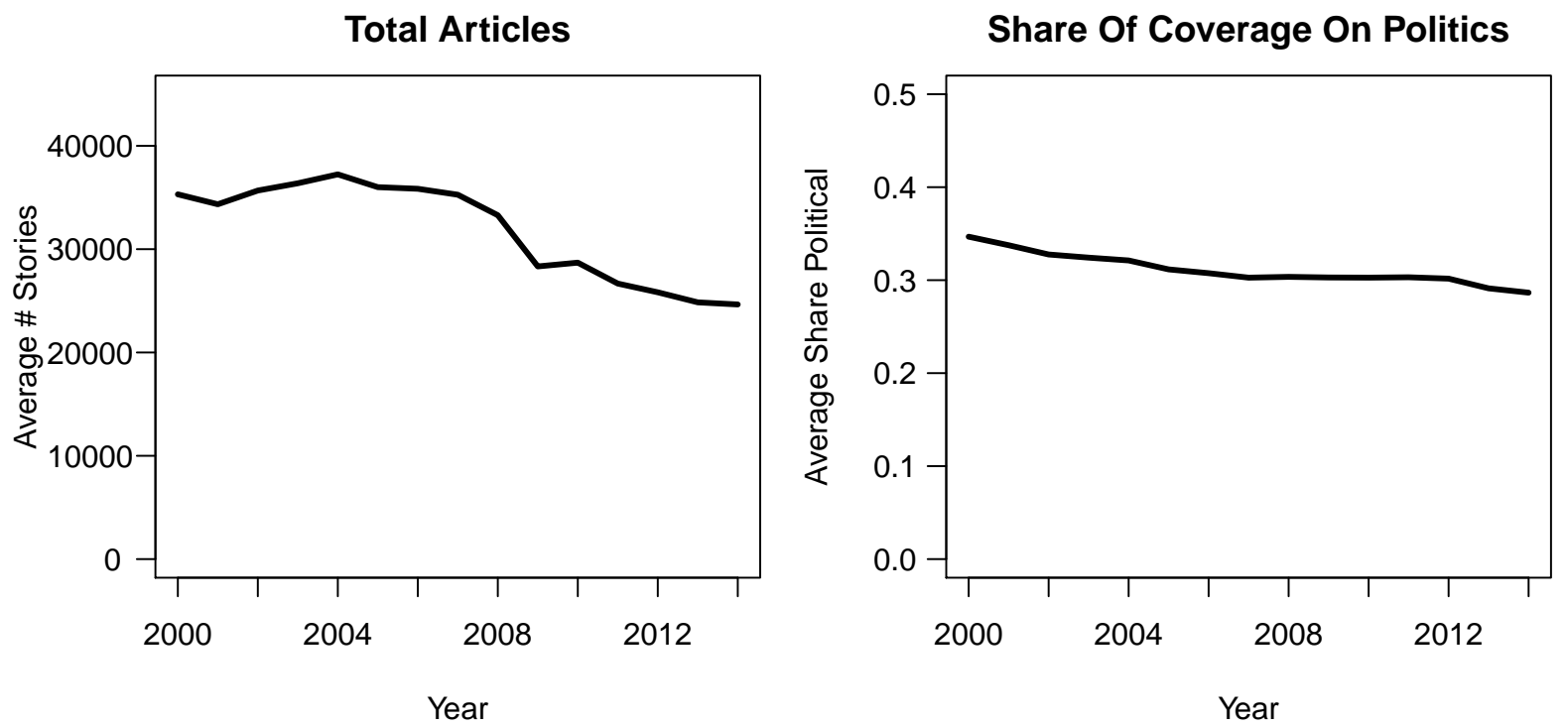

Note: The left panel shows the total number of articles, of any type, available from newspapers. The right panel shows the share of these articles focused on politics

Figure 5 displays the average total number of articles, of any type, in newspapers over this period and the average share of articles focusing on politics. The left panel shows that the overall amount of coverage in newspapers declines during this time period from an average of 35,000 stories in 2000 to 25,000 stories in 2014, a relative decline in coverage similar to the one that occurs when focusing only on political news. The right panel of Figure 5 reflects this 
as the share of political coverage in these newspapers remains relatively stable, falling from $35 \%$ of articles in 2000 to $29 \%$ of articles in 2014 . At the aggregate level, political coverage and non-political coverage fall at relatively similar rates and political coverage share is only slightly reduced reduced by these declines ${ }^{13}$

These aggregate relationships may mask more pronounced changes among individual newspapers after staffing declines occur. For this reason, Table 3 examines this relationship using the two-way fixed effects specification from previous sections. This considers the within-newspaper relationship between staffing declines and the share of a newspaper's coverage devoted to politics.

Table 3: Reporters and Share of Coverage on Politics

\begin{tabular}{lc}
\hline & Newsbank/Census $(1994-2014)$ \\
\hline Reporters & -0.00004 \\
& $(0.00013)$ \\
\hline$N$ & 1470 \\
\hline Robust standard errors, clustered by Newspapers, in parentheses \\
$*$ indicates significance at $p<0.05$
\end{tabular}

In the panel regression the coefficient on staffing is small and indistinguishable from zero. This does not support the second hypothesis put forward earlier as the share of newspaper coverage on politics is not reduced by staffing declines.

When combined, this section establishes that other, non-political areas of coverage (e.g., sports, lifestyle) suffered to a similar degree as political news during this time. As the earlier description of reporting staff composition in Figure 3 showed, the proportional declines in political and non-political domains also extends to the newspaper staffing decisions that occurred over this period. On both counts, this points to the durability of the media outlet

\footnotetext{
${ }^{13}$ Appendix Figure A3 replicates these findings about the overall decline in articles and
} the stable share of coverage focused on politics by examining newspaper scans, rather than the electronic databases used throughout this main analysis. 
structure that earlier studies identify (e.g., Boydstun 2013, Cook 1989), in relative terms, even as absolute levels of political news coverage and newspaper reporting capacity fall substantially.

Evidence that newspaper coverage declines also include non-political news, and that political news is not disproportionately impacted by this shift, is important to consider. For one, it suggests staffing cutbacks may have repercussions for aspects of civic and social life less directly linked to politics (see e.g., Shaker 2014). However, even given this evidence, the reduced volume of political coverage revealed in the preceding sections is still meaningful. The amount of politcal coverage provided by media outlets, rather than the share of a source's coverage focused on political topics, is a key feature of the political information environment examined in previous studies (e.g., Hayes and Lawless 2015, Snyder and Strömberg 2010, Jerit et al. 2006) and this lower volume of coverage, linked to reductions in reporting capacity, means various aspects of politics receive less attention from newspapers.

\section{Staffing Effects by Coverage Type}

I now turn to examining heterogeneity in the effects of staffing on different types of political coverage based on the expectation that a newspaper's reporting capacity should be more strongly related to its coverage of local politics, where information subsidies from other media sources are less readily available, than for coverage of state and national politics. To test this, Table 4 displays estimates from the same regression specifications used to produce Table 1, this time separately estimating the relationship between the number of reporters at a newspaper and its coverage of local politics or national and state politics as the outcome. 
Table 4: Reporters and Political Coverage: By Coverage Type

\begin{tabular}{cccc}
\hline & Local News & National/State News & Difference (Local - National/State) \\
\hline (1) Census/Newsbank & $21.8^{*}$ & $18.3^{*}$ & 3.5 \\
$1994-2014$ & $(8.2)$ & $(7.6)$ & $(5.6)$ \\
(2) Census/Newsbank & $33.5^{*}$ & $26.9^{*}$ & 6.6 \\
2000-2014 & $(7.7)$ & $(5.6)$ & $(5.9)$ \\
(3) Census/Proquest & $30.5^{*}$ & $12.2^{*}$ & $18.3^{*}$ \\
2004-2014 & $(7.7)$ & $(2.0)$ & $(6.8)$ \\
(4) Directory/Proquest & $44.9^{*}$ & $10.0^{*}$ & $34.9^{*}$ \\
2005-2012 & $(7.5)$ & $(1.4)$ & $(6.7)$ \\
\hline
\end{tabular}

Robust standard errors, clustered by Newspaper, in parentheses

Models include Newspaper Fixed Effects, Year Fixed Effects and News Market controls

* indicates significance at $p<0.05$

The first column of Table 4 displays the coefficient on reporting staff with local coverage as the outcome. The second column does the same for models with national/state political news as the outcome. Finally, the third column tests whether reporting resources are more impactful for local coverage by displaying the difference between these two coefficients ${ }^{14}$ Across the different specifications this difference is positive, indicating that reporting resources have a stronger relationship with local coverage relative to national/state political news. However, while the difference between the two coefficients is statistically significant in the models that measure news coverage using Proquest as the outcome variable, they are not when using the Newsbank outcome. This speaks to an inability to reject the null hypothesis of equivalent consequences for changes in reporters across the two types of coverage ${ }^{15}$

Overall, this inconsistent pattern across different operationalization of news exposure does not provide strong support for the third hypothesis. While there is a relatively strong correspondence between measures of political coverage from the two sources (e.g., for newspapers where coverage is available in both Proquest and Newsbank, the correlation between

\footnotetext{
${ }^{14}$ I use a bootstrap, blocked by newspaper, to estimate the uncertainty of the difference between coefficients across the two models.

${ }^{15}$ This same pattern is observed when omitting state-level coverage and only comparing local and national news (see Appendix D.4).
} 
the counts of political stories at a newspaper is 0.75 ), they offer different characterizations of the relative contribution of reporting staff to different types of political news.

The broader array of terms used in the Newsbank search (e.g., moving beyond only searching for specific names of public officials) mutes differences in the relationship between reporting staff for these two areas of political coverage. This indicates there is a loss in national and state oriented political coverage linked to declines in newspaper staffing, beyond stories that only focus on the Presidency or a state's governor, that is similar in magnitude to the decline in its local political coverage. This coverage is included in the Newsbank search, but not in the narrower keywords used when examining coverage in Proquest.

Although Table 4 does not support expectations about the heterogeneous consequences of declines in reporting capacity for different types of political coverage, it further demonstrates the importance of reporting staff for political coverage, showing that a newspaper's reporting capacity has meaningful relationships with both local political coverage and national/state political coverage across the separate models displayed in the table's first two columns.

\section{Staffing Effects by Reporter Roles}

The previous sections pool together different types of reporters when examining the effects of staffing on news coverage. This allows the census and directory-based measures to be used in a similar fashion, but means the measures of reporting staffing include non-news beats (e.g., sports reporters). Since the media directories include reporter beat assignments, this section tests the third hypothesis that politically-focused reporters, relative to general assignment reporters or those focused on entertainment, will have the strongest relationship with the amount of political news coverage produced by a newspaper.

Table 5 presents the results from panel regressions that separate the staffing categories while still employing the newspaper fixed effects, year fixed effects and the control variables used in the prior section. The first three columns consider this relationship using the Proquest measure of political news coverage moving from the specification combining all newspaper 
reporters together (also displayed in Table 1, Model 4), to one that separates entertainment reporters from those on political or general news beats, to one that examines each staffing category individually. The last three columns of Table 5 move through these same steps using the Newsbank measure of coverage, which is available for a slightly larger sample.

Table 5: Reporters and Political News Coverage by Reporter Role (2005-2012)

\begin{tabular}{|c|c|c|c|c|c|c|}
\hline & Proquest & Proquest & Proquest & Newsbank & Newsbank & Newsbank \\
\hline All Reporters & $\begin{array}{l}44.87^{*} \\
(7.48)\end{array}$ & & & $\begin{array}{r}43.21^{*} \\
(19.80)\end{array}$ & & \\
\hline Political/General & & $\begin{array}{l}50.86^{*} \\
(8.70)\end{array}$ & & & $\begin{array}{c}58.02^{*} \\
(25.77)\end{array}$ & \\
\hline Entertainment & & $\begin{array}{c}32.93^{*} \\
(12.80)\end{array}$ & $\begin{array}{c}28.01^{*} \\
(13.70)\end{array}$ & & $\begin{array}{c}15.75 \\
(28.06)\end{array}$ & $\begin{array}{c}28.72 \\
(27.05)\end{array}$ \\
\hline Political & & & $\begin{array}{r}69.06^{*} \\
(12.53)\end{array}$ & & & $\begin{array}{c}24.64 \\
(36.10)\end{array}$ \\
\hline General & & & $\begin{array}{r}24.73^{*} \\
(11.19)\end{array}$ & & & $\begin{array}{l}121.99^{*} \\
(32.58)\end{array}$ \\
\hline$N$ & 1449 & 1449 & 1449 & 1568 & 1568 & 1568 \\
\hline
\end{tabular}

Robust standard errors, clustered by Newspaper, in parentheses

Models include Newspaper Fixed Effects, Year Fixed Effects and News Market controls

* indicates significance at $p<0.05$

There is a consistent pattern when moving from the initial regressions combining all types of reporters to the second specification that separates reporters with non-political beats. The coefficients on the entertainment reporters category are smaller than those for the political/general category. However, in both cases hypothesis tests of the difference between these coefficients fail to reject the null hypothesis that the two categories of reporters have a similar influence on the volume of political coverage available from a newspaper (this difference is 17.9, 95\% Confidence Interval [-12.8, 48.7] for Proquest; 42.3, 95\% Confidence Interval [-33.0, 117.6] for Newsbank).

The similarities between these two samples do not continue when separately considering each of the three staffing categories. In the Proquest sample reporters in the political category have the most pronounced relationship with political news coverage. In contrast, reporters 
in the general category have a stronger relationship with coverage in the Newsbank sample.

These results are not supportive of the fourth hypothesis, as the political reporting category does not have a more pronounced relationship with political news coverage than the others. Even a more qualified comparison based on separating out entertainment reporters from other categories fails to show that the combined set of reporters on political and general news beats makes a stronger contribution to political news relative to those on entertainmentfocused beats. Although there is a difference in the anticipated direction between these two categories, with the coefficient on the entertainment reporters smaller than for reporters on general and political beats, it is imprecisely estimated.

One, admittedly tentative, explanation for the lack of differentiation stems from the stable share of newspaper staff devoted to each of these areas displayed in Figure 3. In the period of staffing declines at newspapers studied here, newspapers that lost political reporters simultaneously lost reporters in other categories. This makes it difficult to distinguish the contribution individual categories of reporters make to political news production. Future work with larger newspaper samples, or conducted during a period in which there is a weaker relationship between declines in reporters on different beats, will be better situated to detect the unique contributions individual categories of reporters make to political coverage.

\section{Discussion and Conclusion}

Decades of research examine the media's influence on mass opinion and elite behavior. However, the large newsrooms that underlie previous findings that newspapers inform the public and sanction public officials no longer exist. While this rapid decline in newspaper reporters has generated alarm from observers, researchers have only recently begun to address its political consequences (e.g., Rubado and Jennings ND, Peterson ND, Hayes and Lawless 2018). Using new data to consider newspaper staffing and coverage during this volatile period, I show that staffing declines reduce the amount of political coverage newspapers offer. This decline in political news occurs alongside similar reductions in non-political 
coverage, highlighting the loss of news with less direct, but potentially still meaningful, civic consequences for future study (e.g., Shaker 2014).

Beyond this focus on overall coverage, there is mixed evidence on the effects of these staff cuts for particular types of coverage (i.e., local political news) and based on the types of reporters involved in them (i.e., reporters with political beats). On both counts, estimates are in the anticipated direction, but there are not detectable differences across the different newspaper samples and measurement approaches used in this study, pointing to the need for future work that examines these claims using larger samples and covering different periods of time. The absence of heterogeneity on these points does have have two clearer implications for understanding political news coverage. First, there is consistent indication that declines in a newspaper's reporting resources matter for its coverage of state and national politics, where alternative information sources are likely available, but also for coverage of local politics, where newspapers represent the primary source of original political reporting and alternatives to legacy media have not emerged. Second, both politically-focused and general assignment reporters have an important role in the production of political news.

A growing body of research considers the political consequences of newspaper shutdowns and changes in local media ownership (Mondak 1995, Schulhofer-Wohl and Garrido 2013, Shaker 2014, Darr et al. 2018, Martin and McCrain 2019). This study broadens the implications of this work on media decline by isolating reduced reporting resources as a factor that shapes the provision of political news coverage for the many newspapers that continue to operate and among newspapers with a variety of ownership structures. This helps explain a source behind the reduced effects of the legacy media observed in several recent studies (Hayes and Lawless 2018, Hayes and Lawless 2015, Peterson ND, see also Hopkins 2018). It also establishes a foundation for further research on the impact of these declines on mass and elite political behavior. Given that much of the reporting on local politics originates in newspapers (e.g., Mondak 1995, Nielsen 2015, Mahone et al. 2019), evidence of the effects 
of staffing declines in this coverage domain suggests the relevance of reporting cutbacks for local political outcomes.

Finally, this evidence contributes to broader discussion about the consequences of economic pressures for political news coverage by illustrating a resource-based channel through which changes in a newspaper's reporting capacity affect aspects of its political coverage. While prior research focuses on how media outlets alter their coverage in anticipation of economic challenges, this account more fully details the consequences when these efforts fall short. This represents an increasingly important theoretical perspective for understanding the relationship between media and politics as many legacy news outlets around the world face increasingly severe economic challenges (e.g., Van Aelst et al. 2017, Nielsen 2015). 


\section{References}

Abernathy, Penolope M. 2018. The Expanding News Desert. University of North Carolina Press.

American Society of Newsroom Editors. 2016. "ASNE releases 2016 Diversity Survey Results." Press Release. Sep 9, 2016. http://asne.org/content.asp?contentid=447

Angelucci, Charles and Julia Cagé. 2019. "Newspapers in Times of Low Advertising Revenues." American Economic Journal: Microeconomics 11(3): 319-364.

Arnold, R. Douglas. 2004. Congress, the Press, and Political Accountability. Princeton University Press.

Ban, Pamela, Alexander Fouirnaies, Andrew B. Hall and James M. Snyder. 2019. "How Newspapers Reveal Political Power." Political Science Research and Methods 7(4): 661678.

Baumgartner, Frank and Bryan D. Jones. 1993. Agendas and Instability in American Politics. University of Chicago Press.

Boydstun, Amber. 2013. Making the News. University of Chicago Press.

Cagé, Julia. ND. "Media Competition, Information Provision and Political Participation: Evidence from French local newspapers and elections, 1944-2014." Journal of Public Economics Forthcoming.

Channick, Robert. 2013. "Chicago Sun-Times Lays Off All Photographers." Chicago Tribune May 30, 2013. http://articles.chicagotribune.com/2013-05-30/business/ chi-chicago-sun-times-photo-20130530_1_chicago-sun-times-photo-staff-video

Cook, Timothy E. 1989. Making Laws and Making News: Media Strategies in the U.S. House of Representatives. Brookings Institution Press.

Darr, Joshua, Matthew Hitt and Johanna Dunaway. 2018. "Newspaper Closures Polarize Voting Behavior." Journal of Communication 68(6): 1007-1028. 
Darr, Joshua. 2016. "Presence to Press: How Campaigns Earn Local Media." Political Communication 33(3): 503-522.

Dunaway, Johanna. 2008. "Markets, Ownership, and the Quality of Campaign News Coverage." Journal of Politics 70(4): 1193-1202.

Edna, Jodi, Katerina Eva Matsa and Jan Lauren Boyles. 2014. “America's Shifting Statehouse Press." Pew Research Center. July 10, 2014. http://www . journalism.org/2014/07/10/americas-shifting-statehouse-press/

Fishman, Mark. 1980. Manufacturing the News. University of Texas Press.

Gardner, Howard, Mihaly Csikszentmihalyi, William Damon. 2001. Good Work: When Excellence and Ethics Meet. Basic Books.

Gentzkow, Matthew and Jesse M. Shapiro. 2010. "What Drives Media Slant? Evidence From U.S. Daily Newspapers." Econometrica 78(1), 35-71.

George, Lisa M. and Joel Waldfogel. 2006. "The New York Times and the Market for Local Newspapers." American Economic Review 96(1), 435-447.

Graber, Doris. 1988. Processing the News. Longman.

Guskin, Emily. 2013. "Newspaper newsrooms suffer large staffing decreases." Pew Research Center: Fact Tank. June 25, 2013. http://www.pewresearch.org/fact-tank/2013/ 06/25/newspaper-newsrooms-suffer-large-staffing-decreases/

Hamilton, James T. 2016. Democracy's Detectives. Harvard University Press.

Hamilton, James T. 2004. All the News That's Fit To Sell: How the Market Transforms Information Into News. Princeton University Press.

Hayes, Danny and Jennifer L. Lawless. 2015. "As Local News Goes, So Goes Citizen Engagement: Media, Knowledge, and Participation in US House Elections." Journal of Politics 77(2), 447-462.

Hayes, Danny and Jennifer L. Lawless. 2018. "The Decline of Local News and Its Effects: New Evidence from Longitudinal Data." Journal of Politics 80(1): 332-336. 
Hopkins, Dan. 2018. The Increasingly United States. University of Chicago Press.

Hopkins, Dan and Lindsay M. Pettingill. 2018. "Retrospective Voting in Big-City US Mayoral Elections." Political Science Research and Methods 6(4): 697-714.

Jerit, Jennifer, Jason Barabas, and Toby Bolsen. 2006. "Citizens, Knowledge, and the Information Environment." American Journal of Political Science 50(2): 266-282.

Jones, Alex S. 2009. Losing the News: The Future of the News That Feeds Democracy. Oxford University Press.

Kaniss, Phyllis. 1991. Making Local News. University of Chicago Press.

Kernell, Georgia, PJ Lamberson and John Zaller. 2018. "Market Demand for Civic Affairs News." Political Communication 35(2): 239-260.

King, Gary, Patrick Lam and Margaret E. Roberts. 2017. "Computer-Assisted Keyword and Document Set Discovery from Unstructured Text." American Journal of Political Science 61(4): 971-988 .

Kirchoff, Suzanne M. 2010. "The U.S. Newspaper Industry in Transition." Congressional Research Service Report 7-5700. https://fas.org/sgp/crs/misc/R40700.pdf

Mahone, Jessica, Qun Wang, Philip Napoli, Matthew Weber and Katie McCollough. 2019. "Who's Producing Local Journalism? Assessing Journalistic Output Across Different Outlet Types." DeWitt Wallace Center for Media \& Democracy Report. https://dewitt. sanford.duke.edu/wp-content/uploads/2019/08/Whos-Producing-Local-Journalism_ FINAL.pdf

Martin, Gregory and Josh McCrain. 2019. "Local News and National Politics." American Political Science Review 113(2): 372-384.

McChesney, Robert W. and John Nichols. 2011. "Down the News Hole." in Will the Last Reporter Please Turn out the Lights (Eds. Robert W. McChesney and Victor Pickard). Pgs 103-113. The New Press.

McManus, John H. 1994. Market-Driven Journalism: Let the Citizen Beware? Sage Publi- 
cations.

Meer, Jonathan and Jeremy West. 2016. "Effects of the Minimum Wage on Employment Dynamics." Journal of Human Resources 51(2), 500-522.

Meyer, Phillip. 2008. The Vanishing Newspaper: Saving Journalism in the Information Age. Second Edition. University of Missouri Press.

Mondak, Jeffrey. 1995. Nothing to Read: Newspapers and Elections in a Social Experiment. University of Michigan Press.

Mummolo, Jonathan and Erik Peterson. 2018. "Improving the Interpretation of Fixed Effects Regression Results." Political Science Research and Methods. 6(4): 829-835.

Nielsen, Rasmus Kleis. 2015. "Local Newspapers as Keystone Media: The Increased Importance of Diminished Newspapers for Local Political Information Environments." in Local Journalism: The Decline of Newspapers and the Rise of Digital Media (Ed. Rasmus Kleis Nielsen), pgs 51-72.

Nielsen, Rasmus Kleis. 2012. Ten Years that Shook the Media World: Big Questions and Big Trends in International Media Developments. University of Oxford: Reuters Institute for the Study of Journalism.

Patterson, Thomas. 2000. Doing Well and Doing Good: How Soft News and Critical Journalism are Shrinking the News Audience and Weakening Democracy. Faculty Research Working Paper Series, RWP01-001. Kennedy School of Government. Harvard University. http://papers.ssrn.com/sol3/papers . cfm?abstract_id=257395

Petrova, Maria. 2011. "Newspapers and Parties: How Advertising Revenues Created an Independent Press." American Political Science Review 105(4), 790-808.

Peterson, Erik. 2017. "The Role of the Information Environment in Partisan Voting." Journal of Politics 79(4), 1191-1204.

Peterson, Erik. ND. "Not Dead Yet: Political Learning from Newspapers in a Changing Media Landscape." Political Behavior Forthcoming. 
Pew Research Center. 2008. "The Changing Newsroom." Pew Research Center Report. July 21, 2008. http://www.journalism.org/2008/07/21/the-changing-newsroom-2/ Prior, Markus. 2007. Post-Broadcast Democracy. Cambridge University Press.

Puglisi, Riccardo and James M. Snyder. 2011. "Newspaper Coverage of Political Scandals." Journal of Politics 73(3), 931-950.

Ridout, Travis, Erika Franklin Fowler and Kathleen Searles. 2012. "Exploring the Validity of Electronic Newspaper Databases." International Journal of Social Research Methodology 15(6): 451-466.

Rogers, Steven. 2017. "Electoral Accountability for State Legislative Roll Calls and Ideological Representation." American Political Science Review 111(3): 555-571.

Rubado, Meghan E. and Jay T. Jennings. ND. "Political Consequences of the Endangered Local Watchdog." Urban Affairs Review Forthcoming.

Schaffner, Brian F. and Patrick J. Sellers. 2003. "The Structural Determinants of Local Congressional News Coverage." Political Communication 20(1): 41-57.

Schulhofer-Wohl, Sam and Miguel Garrido. 2013. "Do Newspapers Matter? Short-run and Long-run Evidence from the Closure of the Cincinnati Post." Journal of Media Economics $26(2), 60-81$.

Seamans, Robert and Feng Zhu. 2014. "Responses to Entry in Multi-Sided Markets: The Impact of Craigslist on Local Newspapers." Management Science 60(2), 476-493.

Shaker, Lee. 2014. "Dead Newspapers and Citizens' Civic Engagement." Political Communication 31(1), 131-148.

Snyder, James M. and David Strömberg. 2010. "Press Coverage and Political Accountability." Journal of Political Economy 118(2), 355-408.

Soroka, Stuart. 2014. Negativity in Democratic Politics: Causes and Consequences. Cambridge University Press.

Starr, Paul. 2009. "Goodbye to the Age of Newspapers (Hello to a New Era of Corruption)." 
The New Republican, March 4, 2009, 28-35.

Starkman, Dean. 2010. "The Hampster Wheel: Why running as fast as we can is getting us nowhere." Columbia Journalism Review. September/October. http://www.cjr.org/cover_story/the_hamster_wheel.php?page=all

Strömberg, David. 2015. "Media and Politics." Annual Review of Economics 7, 173-205.

Trussler, Marc. ND. "Get Information or Get in Formation: The Effects of High Information Environments on Legislative Elections." British Journal of Political Science Forthcoming. Tuchman, Gaye. 1978. Making News: A Study in the Construction of Reality. Free Press. Van Aelst, Peter, Jesper Strömbäck, Toril Aalberg, Frank Esser, Claes de Vreese, Jörg Matthes, David Hopmann, Susana Salgado, Nicolas Hubé, Agnieszka Stepińska, Stylianos Papathanassoupoulos, Rosa Berganza, Guido Legante, Carsten Reinemann, Tamir Sheafer and James Stanyer. "Political Communication in a High-Choice Media Environment: A Challenge for Democracy?" 2017. Annals of the International Communication Association 41(3): 3-27.

Waldman, Steven. 2011. "The Information Needs of Communities: The Changing Media Landscape in a Broadband Age." Federal Communications Commission Report. July 2011. https://transition.fcc.gov/osp/inc-report/The_Information_Needs_of_Communities. pdf

Weaver, David H., Randal A. Beam, Bonnie J. Brownlee, Paul S. Voakes and G. Cleveland Wilhoit. 2007. The American Journalist in the 21st Century. Lawrence Erlbaum Associates.

Zirchhoff, Suzanne M. 2010. "The U.S. Newspaper Industry in Transition." Congressional Research Service Report 7-500. September 9, 2010. 
Supporting Information for:

"Paper Cuts: How Reporting Resources

Affect Political News Coverage" 


\section{Contents}

\begin{tabular}{|ll}
\hline A Appendix A: Measuring News Coverage & 1
\end{tabular}

A.1 Constructing Newspaper Counts (Newsbank Sample) . . . . . . . . . . . . . 1

A.2 Constructing Newspaper Counts (Proquest Sample) . . . . . . . . . . . . . . 1

A.3 Validating Keyword-Based News Coverage Measure . . . . . . . . . . . . . . 2

A.4 Syndicated Coverage in Newspaper Databases . . . . . . . . . . . . . . . . . 6

A.4.1 Availability of Syndicated Coverage in Databases . . . . . . . . . . . 6

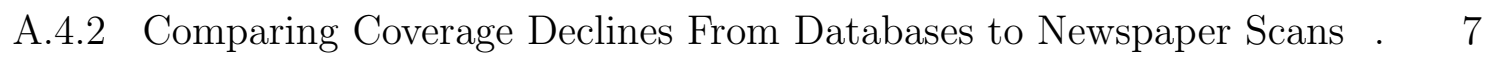

\begin{tabular}{|lr}
\hline B Appendix B: Measuring Newspaper Staffing & 9
\end{tabular}

B.1 Validating Overall Newspaper Staffing Measures . . . . . . . . . . . . . . . . 9

B.2 Determining Reporter Roles . . . . . . . . . . . . . . . . . . . . . 10

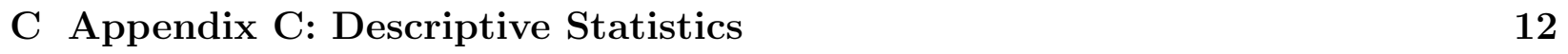

D Appendix D: Estimating the Effect of Staffing on News Coverage Amount 14

D.1 Results Without Covariates . . . . . . . . . . . . . . . . . . . . . 14

D.2 Full Model Results . . . . . . . . . . . . . . . . . . . . . . . . . . . . . 15

D.3 Incorporating Newspaper Ownership . . . . . . . . . . . . . . . . . 16

D.4 Heterogeneity by Coverage Type . . . . . . . . . . . . . . . . . . . . . 17 


\section{A Appendix A: Measuring News Coverage}

\section{A.1 Constructing Newspaper Counts (Newsbank Sample)}

To create a summary measure of newspaper attention to politics, I search for keywords that appear in newspaper articles in the Newsbank database. I use terms employed by Hopkins (2018) to measure attention to politics: ("president" OR "Congress" OR "Senate" OR "White House" OR "congressman" OR "Democrat" OR "Republican" OR "Governor" OR "Lieutenant Governor" OR "Assembly" OR "Legislature" OR "Statehouse" OR "Delegate" OR "Mayor" OR "City Manager" OR "Council" OR "Alderman" OR "Municipal" OR "County Government" OR "City Hall" OR "commissioner" OR "councilmember" OR "township" OR "ordinance"). I append two additional phrases ("school board" or "school district") to capture local education news.

For the analysis of local political coverage from these sources I search for only the following terms: ("Mayor" OR "City Manager" OR "Council" OR "Alderman" OR "Municipal" OR "County Government" OR "City Hall" OR "commissioner" OR "councilmember" OR "township" OR "ordinance" OR "school board" or "school district").

\section{A.2 Constructing Newspaper Counts (Proquest Sample)}

To classify the amount of newspaper coverage available for different political institutions, I used keyword searches of newspapers in the Proquest database. National political coverage was determined using the number of articles mentioning the incumbent president State political coverage was determined by the number of articles mentioning a state's incumbent governor. Local government coverage was determined by articles containing any of the following phrases: ("Mayor" OR "City Council" OR "City Manager" OR "Town Council" OR "Town Manager"). Finally, coverage of local education was determined using the number of articles with the following terms: ("school board" OR "school district"). 


\section{A.3 Validating Keyword-Based News Coverage Measure}

To validate the measures of local education and local government news coverage, I compare the labels based on the keyword search to those assigned to the same documents by a set of coders on Amazon's Mechanical Turk.

I drew a sample of 40 newspapers from the main analysis and collected their entire coverage from Proquest for two weeks each year over the length of the panel. These randomly selected weeks were the 5th (Late January/Early February) and 23rd (Early June) weeks of each year. From this full-text coverage, I used keywords to label an article's topic. For both "Local Education" and "Local Government" I then sampled 250 articles assigned to a category by their keywords and 250 articles labeled outside a category based on their keywords.

Each sampled article was rated by four coders on Amazon's Mechanical Turk. To qualify for this task, coders needed to pass a short 3-item political knowledge quiz, have a greater than 95\% approval rate on their previous HITs and have completed more than 500 total HITs. For both the Local Education and Local Government topic areas, 500 articles received labels.

The coding scheme and instructions for this task are displayed below. 
Figure A1: Local Education Article Coding Task

\section{Local Education News Article Categorization Instructions (Click to expand)}

Please categorize the below local news article based on its Topic.

If multiple categories are appropriate, use the topic that most prominently appears in the text excerpt.

See the Definition below for more details on each category and Examples

Topic

Education Performance

Education Budget

School Policy

School Personnel

Other - Local Education

Other - National Education

Other - NOT Education

\section{Definition}

Educational performance of local school/school district

Spending/taxation in local school/school district

Local school teaching curriculum or policy

Hiring/Firing of teacher, administrator or other school staff

Local school coverage that does not fit above categories

Broader coverage of National, not Local, education

\section{Examples}

Decline/lmprovement in a school's test scores or graduation rate

Budget cuts at local schools. Proposed property tax increase to fund school district. Negotiations with Teacher's Union.

Change to science curriculum in a school. Debate about sex education program in school district.

Hiring new school district superintendent. Firing an elementary teacher.

Coverage of Congressional debates about the No Child Left Behind Bill that does not reference local schools
Title: \$\{title\}

Section: \$\{section\}

$\$\{$ body\}
1) Choose a category:

\begin{tabular}{|c|}
\hline Education Performance \\
\hline Education Budget \\
School Policy \\
\hline School Personnel \\
\hline Other - Local Education \\
\hline Other - National Education \\
\hline Other - NOT Education
\end{tabular}


Figure A2: Local Government Article Coding Task

\section{Local Government News Article Categorization Instructions (Click to expand)}

Please categorize the below local news article based on its Topic.

If multiple categories are appropriate, use the topic that most prominently appears in the text excerpt.

See the Definition below for more details on each category and Examples

Topic

Local Government

Performance

Local Government Budget

Local Government Policy

Local Government

Personnel

Other - Local Government

Other - NOT Local

Government

\section{Definition}

Performance of city or town government

Local government spending (e.g., building new roads, paying city

employees) or revenues (e.g., taxes, grants)

Local government policy decisions

Hiring/Firing town manager or other local government staff

Local government coverage that does not fit above categories

Article is not about local government

\section{Examples}

Decline/Improvement in local crime rate. Business growth in a city.

Budget cuts for municipal government. Proposed property tax increase to fund city. Grant received by a city.

Change to town building codes. New recycling program.

Hiring new town manager. Firing local government employee.
Title: \$\{title\}

Section: \$\{section\}

$\$\{$ body $\}$
1) Choose a category:

Local Government Performance

Local Government Budget

Local Government Policy

Local Government Personnel

Other - Local Government

Other - NOT Local Government 
For local education, labels of "Education Performance", "Education Budget", "School Policy", "School Personnel" or "Other - Local Education" were counted as labeling the article as local education. Labels of "Other - National Education" or "Other - NOT Education" were counted as labeling the article as not about local education.

For local governent, labels of "Local Government Performance", "Local Government Budget", "Local Government Policy", "Local Government Personnel" or "Other - Local Government" were counted as labeling the article as local government. Labels of "Other - NOT Local government" were counted as labeling the article as not about local government.

From these ratings I produce a final label based on the classification offered by a majority of raters. In cases with a 2-2 split, I label the article as "in" the relevant political news category.

This produced a set of 1,000 human-generated article labels (500 Local Education and 500 Local Government) to compare to labels based on keywords. Using the human labels as the benchmark, I consider three standard measures of classifier performance to determine whether keywords effectively identify political news. The first is accuracy. Accuracy is the share of documents where the keyword label agreed with the label from human coders. The second is precision. This is the share of documents labeled as political using the keywordbased approach also labeled political by human coders. The third indicator is recall. This is the share of documents with a political label from human coders that are labeled political using the keyword-based approach. Accuracy captures the overall effectiveness of the keywords. Precision considers whether the keyword-based approach classifies political articles in an overly broad manner that disagrees with human assessments. Recall considers whether the keyword approach captures a substantial portion of the stories assessed as political by human coders (i.e., that the keyword classifier is not too narrow). 
Table A1: Validating Keyword-Based Article Classification

\begin{tabular}{rrr}
\hline & Local Education & Local Government \\
\hline Accuracy & 0.84 & 0.79 \\
Precision & 0.93 & 0.86 \\
Recall & 0.89 & 0.91 \\
\hline
\end{tabular}

Note: Performance of keyword-based article classification relative to labels produced by coders on Amazon's Mechanical Turk

Across these three measures, the keywords accurately capture the intended aspects of news coverage. With respect to local education, the keyword-based approach has an accuracy of 84\%. For determining whether an article focuses on education, it has a precision of 0.93 and recall of 0.89. For local government accuracy is $79 \%$, with a recall of 0.86 and precision of 0.91 for documents assigned to the "local government" category using keywords. This validation shows that the keyword-based approach used to collect this information from the newspaper archives can effectively capture the intended types of coverage.

\section{A.4 Syndicated Coverage in Newspaper Databases}

\section{A.4.1 Availability of Syndicated Coverage in Databases}

Ridout et al. (2012) compare coverage in newspaper databases to the coverage appearing in print for the same newspapers. They identify an issue. Due to copyright restrictions, wire service coverage (e.g., stories from the Associated Press or other syndicated news services) in a newspaper is not always included in newspaper databases. They assess coverage from 2009 and find that $24 \%$ of wire stories in the print version of the newspapers they evaluate appeared in Newsbank and 33\% appeared in Proquest.

To assess the severity of this issue for the newspapers and broader time window considered here, I turn to newspapers.com which has full-text scans of some newspapers. First, I consider the frequency with which wire copy appears in Newsbank by examining the 23 newspapers 
available over the entire 1994-2014 period in the newspaper panel that are also on newspapers.com. On a set of 5 randomly selected days over this time window (11/21/96, 6/13/00, 9/17/04, 9/18/08, 8/11/12), I examined scans of the newspapers to assess wire coverage that appeared in them. I recorded the first five wire stories that appeared in the newspaper and searched to see whether they appeared in that newspaper's coverage in Newsbank. Out of the sample of 550 wire service articles, 145 (26\%) appeared in Newsbank. This number is consistent with what Ridout et al. (2012) observe in their audit of 2009 news coverage. This indicates the databases include some, but not all, syndicated coverage.

\section{A.4.2 Comparing Coverage Declines From Databases to Newspaper Scans}

The absence of some wire coverage raises the possibility that measured declines in newspaper databases exaggerate real-world drops in political news because they miss wire copy included in print editions to offset drops in native political content. For this reason, I drew a sample of 30 newspapers in newspapers.com where the ASNE staffing data was available and, for one randomly selected week from 2000 to 2014 (the 24th week of the year, in the second or third week of June), used scans from newspapers.com to record 1) the total number of daily pages that appeared in the newspaper and 2) the number of daily pages where political keywords used elsewhere in the analysis appeared. It is important to note this page count does not capture individual stories, only the number of pages where at least one political keyword appeared. This is because, unlike the newspaper databases, individual stories are not separated in newspapers.com. Still, this assessment can provide an idea of whether the databases exaggerate declines in political news availability. 
Figure A3: Overall Newspaper Size and Political Coverage Volume from Newspaper Scans
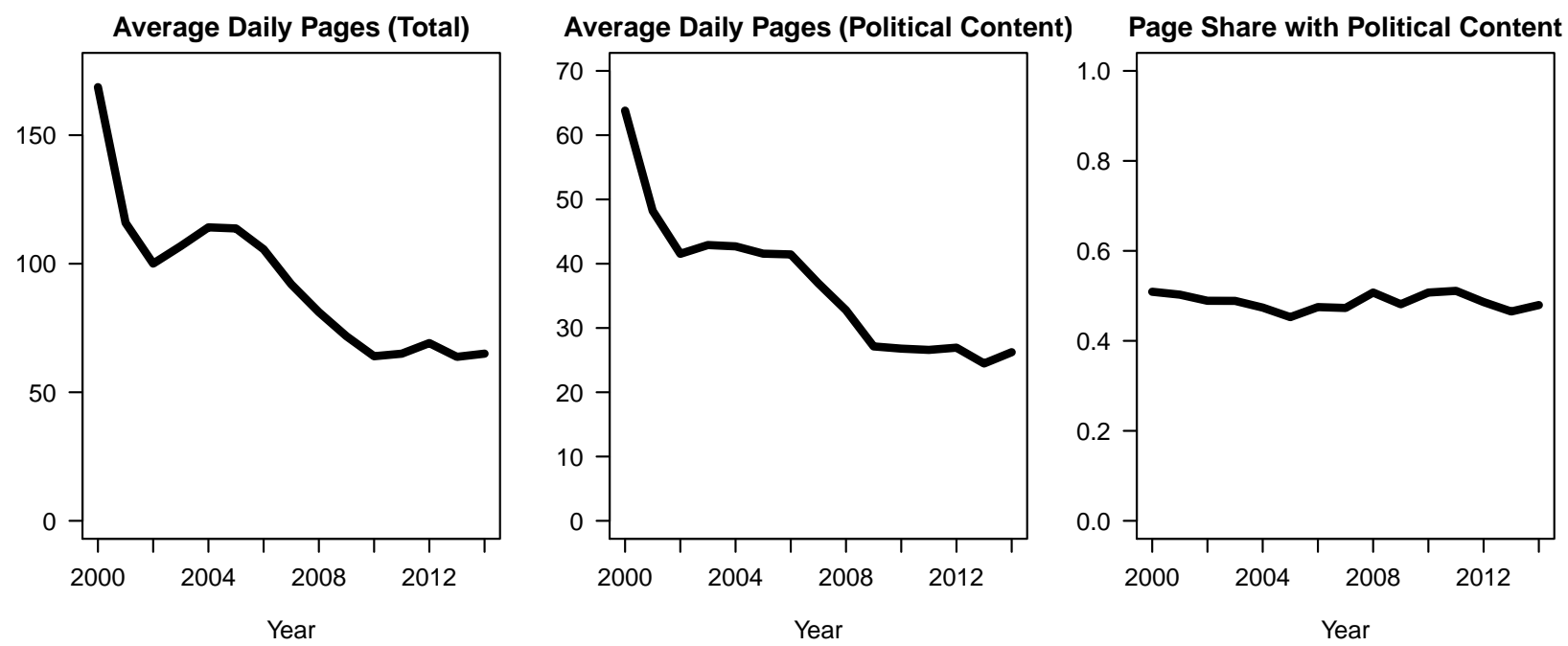

Note: Figure displays average daily coverage by year for 30 newspapers where scans are available.

Figure A3 displays the annual trends in news coverage, showing this alternative approach to measuring news also reveals a steep drop in the overall size of newspapers and their political coverage over this time period, with a concentrated decline in the same window (roughly 2007 to 2009) where pronounced staffing cutbacks occurred.

This sample was selected from newspapers available in both newspapers.com and Newsbank during this time, allowing a comparison of political coverage measures from each. At the newspaper-year level, the correlation between the newspapers.com measure and the annual count of political stories from Newsbank is 0.62 , indicating relatively strong correspondence between these two approaches to measuring political news. For this sample, the annual political coverage output measured in Newsbank drops by 30\% between 2000 and 2014 . Turning to newspapers.com, it drops by $59 \%$ over this period, a more pronounced decline. Across these robustness checks, it does not appear that the database exaggerates declines in the availability of news coverage compared to this other source, even though not all wire service stories are available. 


\section{B Appendix B: Measuring Newspaper Staffing}

\section{B.1 Validating Overall Newspaper Staffing Measures}

Here I consider the validity of the newspaper staffing measures. There is high convergent validity between the two staffing measures. For newspaper-years where both the Census and Dictionary measures are available, the two measures have a correlation of 0.96 .

Beyond the close relationship of these two measures to each other, additional tests indicate they capture relevant dynamics in newspaper staffing. First, the aggregate staffing numbers produced from the ASNE census align closely with the only other aggregate indicator of newspaper employment, a measure of national employment at "Newspaper Publishers" produced by the Bureau of Labor Statistics. The ASNE census aggregate total tracks closely with this industry-wide measure, with the two correlating at .95 for 1990-2015.

Second, I compared publicly available media reports on newspaper layoffs to changes in a newspaper's staffing using the directory measure. To perform this I assembled a list of 49 public newspaper layoffs by searching in the Proquest newspaper database and hand-coding articles discussing a specific job loss amount at a newspaper between 2006 and 2010 .

The figure below displays the relationship between the layoff announcement amount and the change in overall newspaper staffing, based on the directory measure, at the newspaper that year. There is a positive relationship $(r=.6)$ between the two. Newspapers with larger reported layoffs experience larger staffing declines. 
Figure B1: Publicly Reported Layoffs and Staffing Change

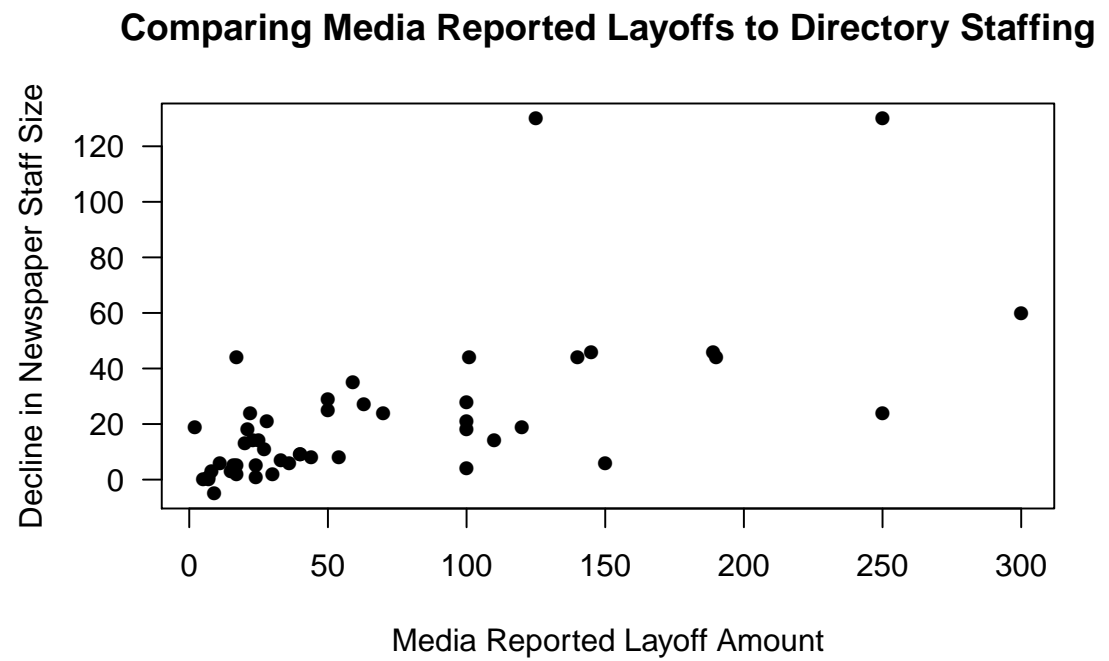

Note: Figure displays 49 instance of publicly reported layoffs and compares the announced size of the layoff to the change in newspaper staffing using the directory measure during that year.

For several reasons there is not a direct 1-to-1 relationship between announced layoffs and changes in staffing in the directory. The layoff announcements often cover an entire newspaper company and, as a result, include support staff that may not be included in the media directories, potentially attenuating this relationship. These layoffs may have also occurred over a longer time window than a single year, delaying the effect of an announcement to later years of a newspaper's staffing. Finally, the directory is only printed once per year and may not indicate departures late in the year until subsequent editions. In other cases these papers may have also made new, less expensive hires to offset buyouts or layoffs of more experienced reporters. Despite these countervailing factors, this measure still appears to capture the consequences of major layoffs.

\section{B.2 Determining Reporter Roles}

Reporters were grouped into three categories - political, general and entertainment - based on terms in the directories. The table below displays the stemmed phrases in a reporter's job 
title that are most commonly associated with each reporting category and the proportion of individuals assigned to that reporting category where a given phrases appears. This shows the group of political reporters includes those working on education, city, county and government news. The group of general reporters includes individuals working on general news assignments and also those focusing on business, retail and transport. Finally, the entertainment category includes those working on sports, health, medicine and food among the most common categories. This offers some face validity for this classification scheme.

Table B1: Phrases Associated with Reporter Roles

\begin{tabular}{rlr|lr|lr}
\hline & Political & Proportion & General & Proportion & Entertainment & Proportion \\
\hline 1 & New & 0.12 & New & 0.13 & Sport & 0.08 \\
2 & Educat & 0.10 & Busi & 0.06 & Health & 0.05 \\
3 & Citi & 0.06 & Transport & 0.03 & Medicin & 0.04 \\
4 & Counti & 0.05 & Retail & 0.03 & Contribut & 0.02 \\
5 & Polit & 0.05 & Senior & 0.03 & Columnist & 0.02 \\
6 & Commun & 0.05 & Bank & 0.03 & Food & 0.02 \\
7 & Govern & 0.04 & Contribut & 0.03 & Industri & 0.02 \\
8 & Court & 0.04 & Industri & 0.02 & School & 0.02 \\
9 & Polic & 0.03 & Real & 0.02 & High & 0.02 \\
10 & State & 0.03 & Estate & 0.02 & Art & 0.02 \\
11 & Region & 0.03 & East & 0.02 & Healthcar & 0.02 \\
12 & Local & 0.02 & Middl & 0.02 & Religion & 0.01 \\
13 & Higher & 0.02 & Financ & 0.02 & Review & 0.01 \\
14 & Metro & 0.02 & Economi & 0.02 & Home & 0.01 \\
15 & Crime & 0.02 & Environ & 0.02 & Senior & 0.01 \\
16 & Hall & 0.02 & Consum & 0.02 & Basebal & 0.01 \\
17 & Project & 0.01 & Energi & 0.01 & Pop & 0.01 \\
18 & Investig & 0.01 & Europ & 0.01 & Collegi & 0.01 \\
19 & Special & 0.01 & Small & 0.01 & Featur & 0.01 \\
20 & Feder & 0.01 & Immigrat & 0.01 & Entertain & 0.01 \\
\hline
\end{tabular}




\section{Appendix C: Descriptive Statistics}

Table C1 describes the mean and standard deviations of the variables used in the analysis for the sample of newspapers available from 1994-2014. This provides context for the variation in newspaper staffing and newspaper coverage discussed in the main text.

Table C1: Descriptive Statistics: 1994-2014 Newspaper Sample

\begin{tabular}{rrr}
\hline Variable & Mean & Standard Deviation \\
\hline Total Coverage & 32834.80 & 19905.63 \\
Share Political Coverage & 0.20 & 0.04 \\
Political Stories & 10578.01 & 6787.15 \\
Local Political Stories & 5459.92 & 3866.98 \\
Total Reporters & 67.26 & 47.54 \\
Circulation & 150760.79 & 112941.95 \\
Population (Home County) & 839597.71 & 1218333.53 \\
Share White (Home County) & 0.73 & 0.14 \\
Median Income (Home County) & 55747.99 & 10246.78 \\
Share Bachelors Degree (Home County) & 0.28 & 0.08 \\
\hline
\end{tabular}

Table C2 (the 1994-2014 sample of newspapers where coverage is available in Newsbank) and Table C3 (the 2004-2014 sample of newspaper where coverage is available in Proquest) focus on political news coverage and display the average levels of political coverage across different topics over this time period. 
Table C2: Political Coverage by Year (Newsbank)

\begin{tabular}{rrrrr}
\hline & Year & Political (All) & Political (Local Only) & Political (Share Local) \\
\hline 1 & 1994.00 & 12971.00 & 6389.60 & 0.49 \\
2 & 1995.00 & 12398.60 & 6126.80 & 0.49 \\
3 & 1996.00 & 12548.70 & 6175.10 & 0.49 \\
4 & 1997.00 & 12176.50 & 6239.80 & 0.51 \\
5 & 1998.00 & 12485.00 & 6235.00 & 0.50 \\
6 & 1999.00 & 12409.50 & 6426.60 & 0.52 \\
7 & 2000.00 & 12099.40 & 6266.90 & 0.52 \\
8 & 2001.00 & 11501.80 & 6034.00 & 0.52 \\
9 & 2002.00 & 11489.20 & 6170.30 & 0.54 \\
10 & 2003.00 & 11572.90 & 6133.00 & 0.53 \\
11 & 2004.00 & 11702.60 & 6007.90 & 0.51 \\
12 & 2005.00 & 11042.00 & 5920.80 & 0.54 \\
13 & 2006.00 & 10870.20 & 5765.70 & 0.53 \\
14 & 2007.00 & 10562.20 & 5729.20 & 0.54 \\
15 & 2008.00 & 9945.30 & 5107.10 & 0.51 \\
16 & 2009.00 & 8430.50 & 4299.00 & 0.51 \\
17 & 2010.00 & 8430.10 & 4415.00 & 0.52 \\
18 & 2011.00 & 7938.50 & 4175.80 & 0.53 \\
19 & 2012.00 & 7684.20 & 3930.40 & 0.51 \\
20 & 2013.00 & 7130.00 & 3643.60 & 0.51 \\
21 & 2014.00 & 6749.90 & 3466.60 & 0.51 \\
\hline
\end{tabular}

Table C3: Political Coverage by Year (Proquest)

\begin{tabular}{rrrrrrr}
\hline & Year & Local Ed & Local Gov & State & National & Political (Share Local) \\
\hline 1 & 2004.00 & 1958.60 & 2158.50 & 488.90 & 1129.50 & 0.72 \\
2 & 2005.00 & 1864.10 & 2123.30 & 509.80 & 792.10 & 0.75 \\
3 & 2006.00 & 1762.70 & 1848.00 & 438.50 & 651.60 & 0.77 \\
4 & 2007.00 & 1738.80 & 1850.30 & 443.90 & 569.50 & 0.78 \\
5 & 2008.00 & 1623.20 & 1706.00 & 417.00 & 536.80 & 0.78 \\
6 & 2009.00 & 1454.00 & 1517.70 & 416.80 & 885.20 & 0.70 \\
7 & 2010.00 & 1487.20 & 1512.00 & 397.80 & 607.90 & 0.75 \\
8 & 2011.00 & 1372.40 & 1442.50 & 481.20 & 509.90 & 0.74 \\
9 & 2012.00 & 1366.60 & 1389.50 & 406.10 & 661.60 & 0.72 \\
10 & 2013.00 & 1491.60 & 1488.20 & 451.60 & 536.60 & 0.75 \\
11 & 2014.00 & 1438.90 & 1467.00 & 459.70 & 526.90 & 0.75 \\
\hline
\end{tabular}




\section{Appendix D: Estimating the Effect of Staffing on News Coverage Amount}

\section{Newspaper-Market Controls}

A newspaper's home county was determined using the 2015 Editor and Publisher Databook.

The Market Share and Competition variables are only available from 2004 to 2014. They are not included as controls in the panels that begin before this time period. I linearly interpolate covariates for the years in between these measures.

Table D1: Control Variables

\begin{tabular}{|l|l|l|}
\hline Variable Name & Description & Source \\
\hline Market Share & Share of newspaper circulation in home county & SRDS Subscription (2004, 2008), AAM Database (2014) \\
Competition & Number of other papers with sales in home county & SRDS Subscription (2004, 2008), AAM Database (2014) \\
Circulation & Average weekday sales & Editor and Publisher (1992, 1996, 2000, 2004, 2008, 2012, 2014) \\
Population & Population in home county & Census (1990, 2000, 2010), Current Population Survey (2014) \\
\% White & \% white residents in home county & Census (1990, 2000, 2010), Current Population Survey (2014) \\
Median Income & Median income in home county & Census (1990, 2000, 2010), Small Area Income Estimates (2014) \\
\% Bachelors & \% residents with a Bachelor's in home county & Census (1990, 2000, 2010), Current Population Survey (2014) \\
\hline
\end{tabular}

\section{D.1 Results Without Covariates}

These control variables are used to account for alternative explanations for a decline in the amount of political news coverage that a newspaper provides. However, these controls also potentially complicate the interpretation of the coefficient on reporting resources. For example, a decline in newspaper staffing may also shape a newspaper's circulation, introducing bias into estimates of the effects of newspaper staffing.

For this reason, Table D2 reproduces results from the two-way fixed effects models used in Table 1 of the the main text, this time estimating the relationship between staffing and overall news coverage without other covariates. 
Table D2: Reporters and Overall Political News Coverage (No Controls)

\begin{tabular}{lrrrr}
\hline & Model 1 & Model 2 & Model 3 & Model 4 \\
\hline Reporters & $79.77^{*}$ & $93.16^{*}$ & $42.61^{*}$ & $46.53^{*}$ \\
& $(14.22)$ & $(11.66)$ & $(7.10)$ & $(7.11)$ \\
\hline$N$ & 1470 & 2880 & 1606 & 1449 \\
\hline Coverage Source & Newsbank & Newsbank & Proquest & Proquest \\
Staffing Source & Census & Census & Census & Directory \\
Time Period & $1994-2014$ & $2000-2014$ & $2004-2014$ & $2005-2012$ \\
\hline
\end{tabular}

Robust standard errors in parentheses

Models include Newspaper Fixed Effects and Year Fixed Effects

* indicates significance at $p<0.05$

The coefficients on reporting resources are markedly larger for Models 1 and 2, which cover the longest time period. The magnitude of the coefficient on reporting resources in Model 1 doubles when additional covariates are excluded. In Model 2 the coefficient increases by roughly one-third compared to its initial magnitude in the model with controls. In contrast, the two estimates over the shorter time window remain similar to the models in Table 1.

This robustness check helps to show the results reported in the main text do not hinge on the use of these additional covariates. The implications of this analysis, that declines in reporting resources reduce the volume of political coverage newspapers produce, remain similar when covariates are not included.

\section{D.2 Full Model Results}

The in-text models omit the additional covariates for clarity. Here the full tables with the additional control variables that are included are displayed. 
Table D3: Reporters and Overall Political News Coverage

\begin{tabular}{lrrrr}
\hline & Model 1 & Model 2 & Model 3 & Model 4 \\
\hline Reporters & $40.15^{*}$ & $60.38^{*}$ & $42.68^{*}$ & $44.87^{*}$ \\
& $(14.71)$ & $(11.96)$ & $(9.23)$ & $(7.48)$ \\
Circulation & $0.03^{*}$ & $0.02^{*}$ & -0.00 & -0.00 \\
& $(0.01)$ & $(0.01)$ & $(0.00)$ & $(0.00)$ \\
Population & $-0.01^{*}$ & -0.00 & -0.00 & -0.00 \\
& $(0.00)$ & $(0.00)$ & $(0.00)$ & $(0.00)$ \\
White Share & 8029.46 & 949.70 & 606.13 & 7153.81 \\
& $(14777.20)$ & $(6350.09)$ & $(4077.55)$ & $(7191.54)$ \\
Median Income & $0.34^{*}$ & 0.09 & 0.05 & 0.10 \\
& $(0.16)$ & $(0.05)$ & $(0.05)$ & $(0.06)$ \\
Bachelors Degree & -31386.35 & -22352.41 & -6020.33 & 932.36 \\
& $(25406.41)$ & $(12826.43)$ & $(10071.90)$ & $(11489.28)$ \\
Market Share & & & 1067.07 & 1026.72 \\
& & & $(767.29)$ & $(1678.42)$ \\
Paper Competition & & & 52.63 & 24.66 \\
& & & $(40.05)$ & $(29.54)$ \\
\hline$N$ & 1470 & 2880 & 1606 & 1449 \\
\hline & Robust standard errors in parentheses \\
$*$ & & &
\end{tabular}

\section{D.3 Incorporating Newspaper Ownership}

I also examine whether these findings change when incorporating newspaper ownership into the analysis. To do this I began with data on newspaper ownership collected by Abernathy (2018) for 2004 and 2019 and determined the owner of each newspaper in the coverage/staffing samples covering 2004 to 2014. I then incorporate within-newspaper changes in ownership into the analysis presented in the main text. I define national chains like earlier work (e.g., Schaffner and Sellers 2003) as large owners of multiple newspapers spread across the country. For the newspapers in this sample, this consists of: Digital First/MediaNews, Gannett, GateHouse, Lee Enterprises, Tribune Company and McClatchy/Knight Ridder. The remaining newspapers were owned by small regional chains or individual owners.

The table below re-estimates the in-text models after including media ownership. 
Table D4: Reporters/Ownership and Political Coverage

\begin{tabular}{lcr}
\hline & Model 1 & Model 2 \\
\hline Reporters & $43.21^{*}$ & $45.48^{*}$ \\
& $(9.49)$ & $(7.57)$ \\
National Chain & $-1016.16^{*}$ & $-749.87^{*}$ \\
& $(373.53)$ & $(282.88)$ \\
\hline$N$ & 1606 & 1449 \\
\hline Coverage Source & Proquest & Proquest \\
Staffing Source & Census & Directory \\
Time Period & $2004-2014$ & $2005-2012$ \\
\hline Robust standard errors, clustered by newspaper, in parentheses \\
${ }^{*}$ indicates significance at $p<0.05$
\end{tabular}

Consistent with previous studies, national chain ownership is related to less political coverage from an outlet. However, the inclusion of this variable does not alter the relationship between newspaper staffing and political coverage, which remains similar to the estimates reported in the main text even after accounting for changes in ownership over this time period. This points to changes in staffing and changes in ownership as distinct influences on the volume of political news coverage that a newspaper produces during this time period.

\section{D.4 Heterogeneity by Coverage Type}

Table 4 in the main text examines differences in the effect of staffing for local political coverage and a combination of national and state political coverage. This is done because there are more possibilities for newspapers to draw on information from other media sources in order to cover state and national politics. The table below reconsiders this relationship after dropping state-level coverage. This reveals a similar pattern to the results in the main text as, when using the Proquest measure, newspaper staffing has a stronger relationship with local political coverage than other forms of news coverage. 
Table D5: Reporters and Political Coverage: By Coverage Type

\begin{tabular}{rrrr}
\hline & Local News (1) & National News (2) & Difference $(1-2)$ \\
\hline Census/Proquest & 30.49 & 8.84 & 21.65 \\
2004-2014 & $(7.66)$ & $(1.69)$ & $(7.18)$ \\
Directory/Proquest & 44.87 & 6.18 & 38.69 \\
$2005-2012$ & $(7.48)$ & $(1.13)$ & $(7.02)$ \\
\hline
\end{tabular}

